OPEN ACCESS

Citation: Francesco Di Filippo, Federico Manuelli (2021) Hic sunt leones. Iconographic analysis and computational modelling for the study of the Iron Age free-standing lions of the Elbistan plain (south-eastern Anatolia). Asia Anteriore Antica. Journal of Ancient Near Eastern Cultures 3: 43-72. doi: 10.36253/ asiana-1204

Copyright: @ 2021 Francesco Di Filippo, Federico Manuelli. This is an open access, peer-reviewed article published by Firenze University Press (http:// www.fupress.com/asiana) and distributed under the terms of the Creative Commons Attribution License, which permits unrestricted use, distribution, and reproduction in any medium, provided the original author and source are credited.

Data Availability Statement: All relevant data are within the paper and its Supporting Information files.

Competing Interests: The Author(s) declare(s) no conflict of interest.

\section{Hic sunt leones. Iconographic analysis and computational modelling for the study of the Iron Age free-standing lions of the Elbistan plain (south-eastern Anatolia)}

\author{
Francesco Di Filippo ${ }^{1}$, Federico Manuelli ${ }^{2}$ \\ ${ }^{I}$ Institute for Studies on the Mediterranean (CNR - ISMed), Rome \\ ${ }^{2}$ Institute of Heritage Science (CNR - ISPC), Rome and Institut für Altorientalistik \\ (FU Berlin), Berlin \\ francesco.difilippo@cnr.it; federico.manuelli@cnr.it
}

\begin{abstract}
Lying between the central Anatolian plateau and the Euphrates region, the Elbistan plain represents an ideal environment for inspecting forms of cultural interconnection. During the Iron Age, this territory was marked by the presence of notable inscribed monuments, the study of which allowed scholars to establish relationships with the most significant Neo-Hittite dynasties. This region is also characterized by the presence of sets of anepigraphic portal lions, positioned seemingly at random in the open landscape and with no apparent relationship with coeval archaeological remains, which have never been concretely integrated into the historical picture. In this contribution, the iconographic and stylistic analysis of these sculptures will allow us to situate them in their chronological and historical framework. A computational spatial model is further used to evaluate the meaning of their positioning as markers of a visual networking system that may have represented the most significant thoroughfares to and from the Elbistan plain.
\end{abstract}

Keywords. Elbistan plain, Iron Age, Euphrates region, Free-standing lions, SyroAnatolian art, Settlement pattern, Semi-automated landform classification, Least Cost Paths.

\section{INTRODUCTION: BACKGROUND AND GOALS}

Since the mid-19 ${ }^{\text {th }}$ century AD, German and British explorers travelling across the Taurus regions reported the presence of two free-standing stone lions located approximately $15 \mathrm{~km}$ south of Darende, in the middle of the soft foothills at the northern border of the Elbistan plain in central-eastern Anatolia. ${ }^{1}$ Because of their presence the spot has always been referred to

${ }^{1}$ A detailed synthesis is reported by Hawkins (2000: 329). 
by local inhabitants as 'Arslantaş' (lion stone) (Fig. 1). Not much attention has been typically dedicated to these sculptures and the lions have generally been mentioned as indicators of the presence of a gateway, drawing on comparisons with similar stone guardians known from the Assyrian palaces (Sterret 1888: 299). Only later was the attention of scholars drawn to the fact that these standing in situ sculptures seem not to be associated with any building or even any proper site (Hawkins 2000: 329), representing an isolated piece of archaeological evidence in the open countryside (Özgüç, Özgüç 1949: 63-64).

Approximately $35 \mathrm{~km}$ southeast of Arslantaş, at the eastern border of the Elbistan plain, a second pair of standing lions has been found in the proximity of the village of Sevdiliköy. They were moved in 1961 to the local museum of Kahramanmaraş (Eralp 1995). Nowadays, only one of the two sculptures is exhibited, while the second is kept in the museum storehouse. Their original location was on top of a rock outcrop which probably also represents the quarry from which the lions had been realized (Orthmann 1971: 533). Indeed, according to the locals, the sculptures had been found here lying on their sides.

Once again at the beginning of the 1960s, a single lion sculpture was discovered in the village of Hunu/ Arıtaş, at the western edge of the Elbistan plain (Kökten 1960: 43; Dumankaya, Topaloğlu 2017: 291). Despite the fact that the village was built on top of a mound (the so-called Arıtaş Höyük), it is still debatable whether the sculpture was originally located on the site. The fact that the lion was left unfinished and/or reused allows us to assume that it was only later transported and employed at the site. In any case, the sculpture was moved to the Kahramanmaraş museum, where it is still currently exhibited.

The standing lions of the Elbistan plain have never been the focus of any specific analysis. Travelers and scholars have long argued over whether the lions from Arslantaş could have been given one or more inscriptions (Ramsay, Hogarth 1893: 92-96; Charles 1911: 31-35; Meriggi 1975: 316; Hawkins 2000: 329). Nowadays, there are still

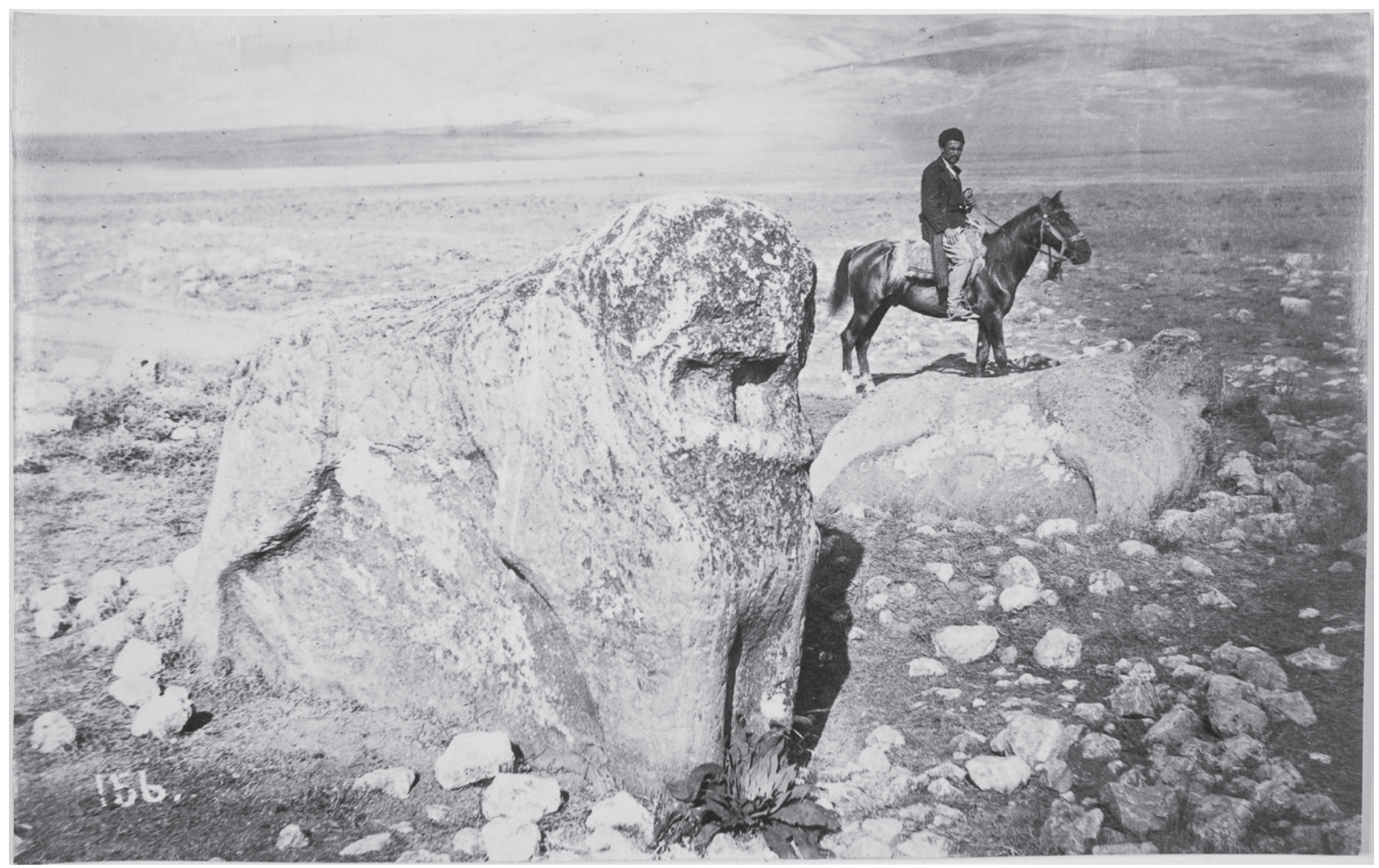

Fig. 1: The lions of Arlantaş in 1881 or 1882. Credit: John Henry Haynes archive, courtesy of Special Collections, Fine Arts Library, Harvard University. 
doubts about the location and even the existence of any potential inscription(s) and the continuous exposure of the lions to the austere winter conditions of the Anatolian plateau will certainly not improve the situation.

Very few attempts have also been made to set the three groups of sculptures within their chronological and cultural context through iconographic and stylistic comparisons (Özgüç, Özgüç 1949: 64; Orthmann 1971: 118; Eralp 1995: 118-119). Moreover, the sculptures have hardly ever been considered as a coherent whole or analyzed in order to understand their possible meaning and their relationships and positioning within the surrounding territory (Harmanşah 2011: 77, Fig. 3).

However, their main characteristics stand out at first glance. First of all, they are unique in the whole context of Syro-Anatolian art, considering that they are the only lions carved on all their surfaces and arranged to be seen for a full four-side view. ${ }^{2}$ Second, their location is anything but random, since they are all positioned in strategic areas marking the existence of possible passages and accesses from and to their territory as well as a special relationship with the surrounding landscape.

When plotted on a map along with the rest of the archaeological evidence of the Elbistan region, the portal lions of Arslantaş, Sevdiliköy, and Hunu immediately evoke an impressive significance. Indeed, they all border the outer fringes of the inhabited plain, distanced from any other settlement of the region (Fig. 2).

The following pages present the lions from the Elbistan plain. Their main iconographic and stylistic characteristics will be described and situated within the corpus of the Syro-Anatolian art. Their positioning will be then evaluated within the surrounding territory through computational spatial models and their symbolic, political, and historical meanings will be further discussed.

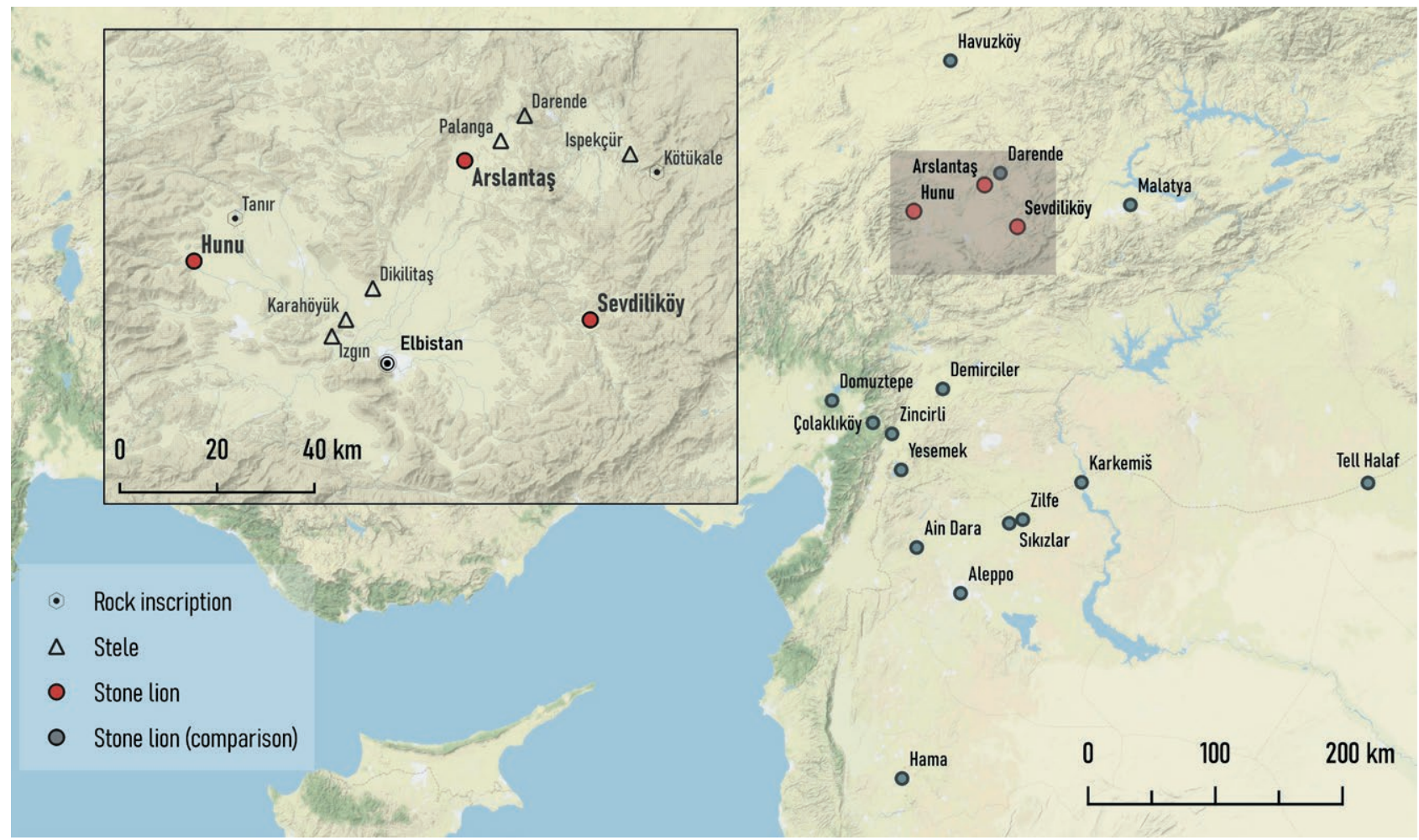

Fig. 2: Map of the study area with cited toponyms. Base map by Stamen Design, CC-BY-3.0.

\footnotetext{
2 The term 'Syro-Anatolian' is used here to identify the region that geographically includes south-eastern Turkey and north-eastern Syria. For the use of different terminologies in accordance with historical, geographical or ethnic issues see Gilibert (2011: 1-6).
} 


\section{ICONOGRAPHY AND STYLE}

\subsection{Description}

The most renowned case of this fascinating group of sculptures is represented by the couple of still in situ portal lions from Arslantaş (Fig. 1). ${ }^{3}$ The lions are free-standing and only the stone blocks underneath the bodies and between the legs were not sculpted away. This resulted in an almost fully three-dimensional shape where the body details are carved for a four-side view and the shoulders and hind legs are seen sideways (Fig. 3).

This provides the sculptures with a peculiar natural stance, as is also stressed by their upper outline that steeply follows the curve of the animals' spines. The lions are relatively slender with slightly rounded edges and smoothed surfaces. Shoulders and hind legs are separated from the torso by well-defined and soft curves. The limbs are elongated and slim, but they look rather stiff and immobile, despite the front legs being slightly advanced. The heads are three-dimensionally figured all around and conceived for a multi-side view. However the unnatural position of the heads should be noted - completely retracted and embedded into the shoulders - as well as their cubic, unusually long and wide proportions.

The rendering of the animals' details is unfortunately not always easily comprehensible. This is especially evident on lion B, where the details of the muzzle are almost completely washed away. The lions' mouths are open wide with a hanging tongue just slightly visible on lion A (Fig. 4). The lips are round and large while the fangs, probably originally four sharp pointed shapes, are now only discernible by means of two conical bulges. The upper parts of the muzzles are deeply damaged, so as not to allow for a precise reconstruction of their details. This generates a bizarre perception of the mouths, as though they were wider than the originals. The outline of a broad nose
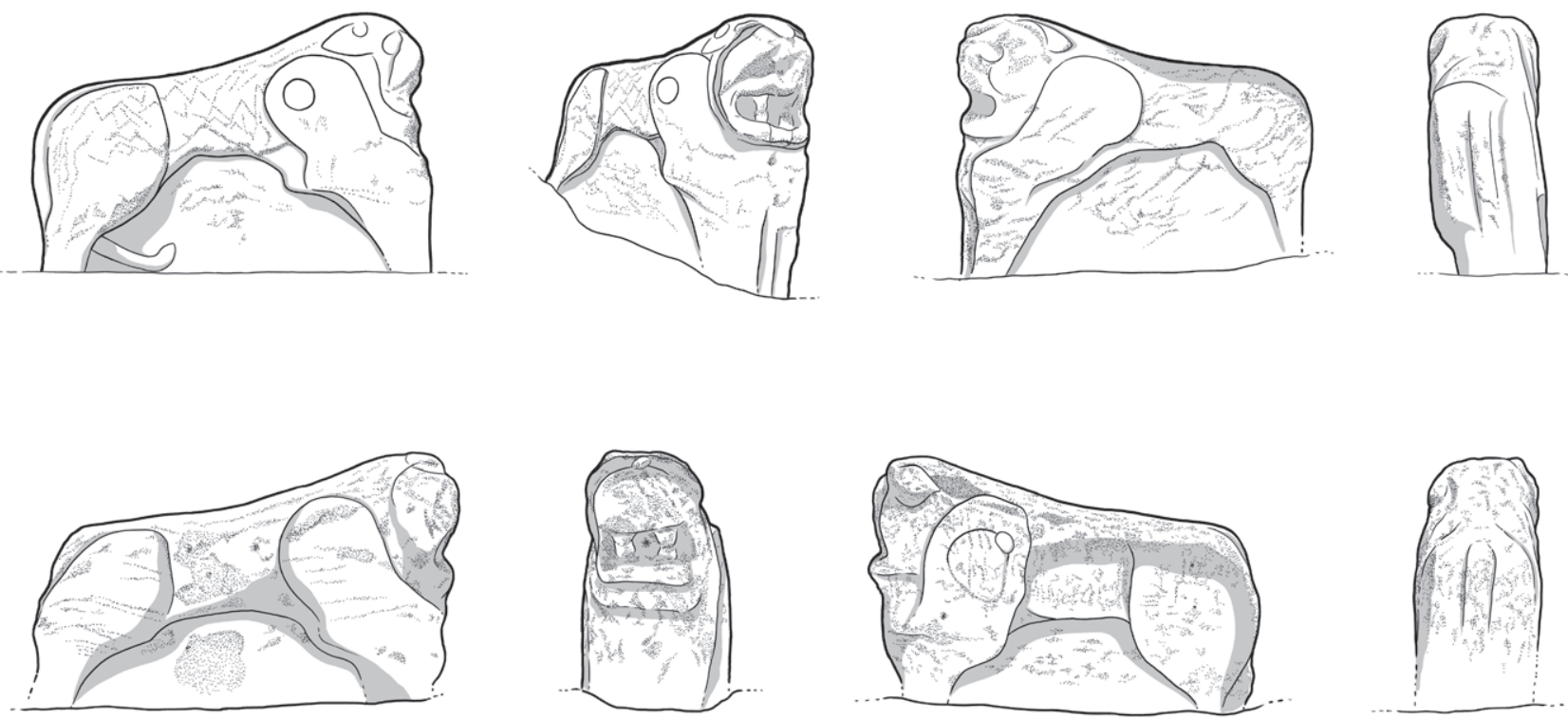

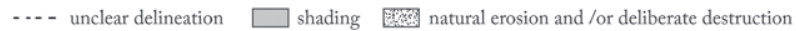

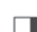

Fig. 3: The lions of Arlantaş: lion A (top) and lion B (bottom). Drawings by R. Zaher based on: Özgüç, Özgüç 1949 and Bilgin 2021.

\footnotetext{
${ }^{3}$ We follow here the numeration proposed by Hawkins (2000: 329) who identified lion A with the one on the left entering the potential 'gate' and lion B on the right. The sculptures are made of limestone and are placed at approximately four meters distance to each other; lion A is $2.05 \mathrm{~m}$ in height and $2.55 \mathrm{~m}$ in length, lion B is $1.95 \mathrm{~m}$ in height and $2.55 \mathrm{~m}$ in length (Özgüç, Özgüç 1949: 64).
} 
is in any case visible especially on lion A. The eyes of the animals are also wide with the upper orbital parts rounded and notably protruding.

Despite the absence of a neck due to their posture, the muscles that surround the animals' heads are rendered by a soft band that is still partially visible only on the external side of lion A that merges with the above-mentioned protruding eye socket. The cheek musculature is also very prominent and is especially emphasized on the external side of lion A. The ear shape is in contrast almost totally indiscernible. They give the impression of being large, retreated, and triangular (Fig. 5).

Despite the fact that they are characterized by rounded and well-defined shoulders, the forelegs are out of proportion: extremely wide on the upper part and thinner in the lower one. Moreover, the joint between the two segments is characterized by a very unnatural angle that recalls a protruding spur, as is especially noticeable on the back of the external foreleg of lion A. On the same lion, the upper sides of both forepaws are also visible, and are characterized by four elongated and stylized claws (Fig. 6). Unfortunately, their ends on both the front and the lateral sides cannot be reconstructed because they are hidden by the soil of the field.

A thick mane entirely covers the external sides of the upper parts of both lions, approximately down to the belly line and reaching almost the limit of the hind leg (Fig. 5). On lion A, the mane recalls a pattern characterized by irregular lozenges or leaf-shapes that overlap both the fore and the back shoulders. This is less readable on lion $\mathrm{B}$, where the limestone encrustations and a series of irregular grooves on the surface have been weathered, giving the impression of the presence of some rude circular patterns. This might also be a consequence of the long period spent by the lion lying on this side and touching the earth.

The bodies are slim, and the abdomens are rendered with an arch shape that is extremely stretched and thin on lion A but heavier and more solid on lion B. As far as the hind legs are concerned, they are also well
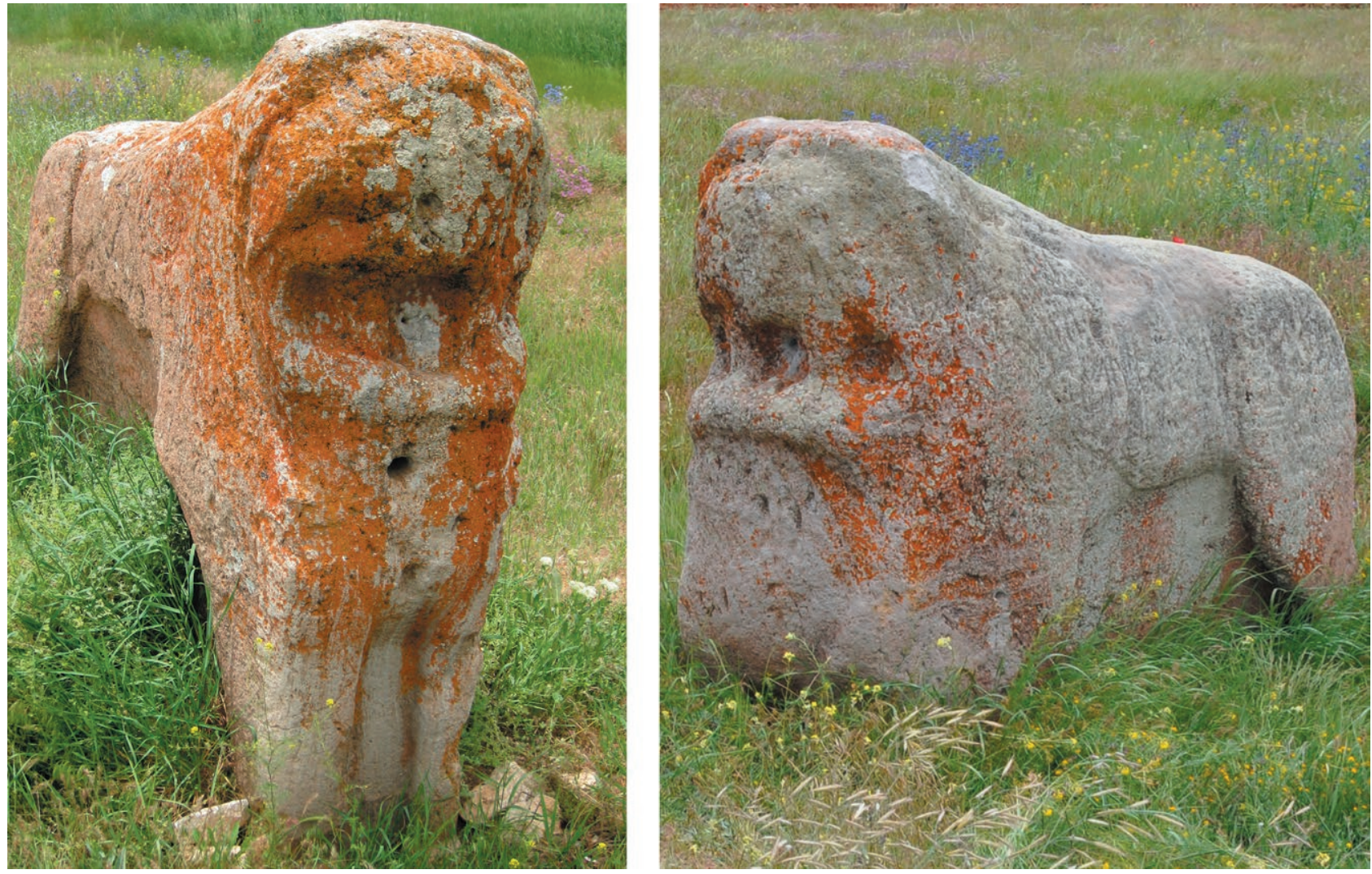

Fig. 4: Arlantaş in 2011, the lions' head: lion A (left) and lion B (right). Credit: Bilgin 2021. 

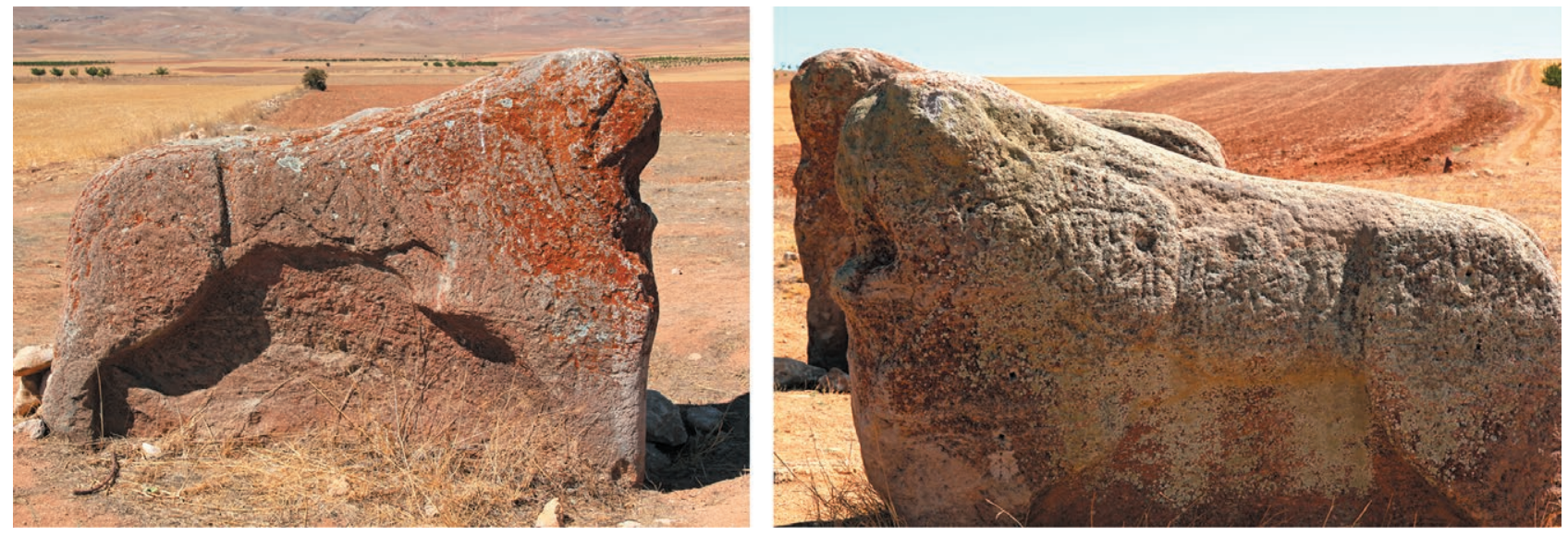

Fig. 5: Arlantaş in 2014, the lions' external foreside: lion A (left) and lion B (right). Credit: Wikimedia Commons, https://commons.wikimedia.org/wiki/Category:Aslanta\%C5\%9F_(Darende), CC-BY-SA-3.0.
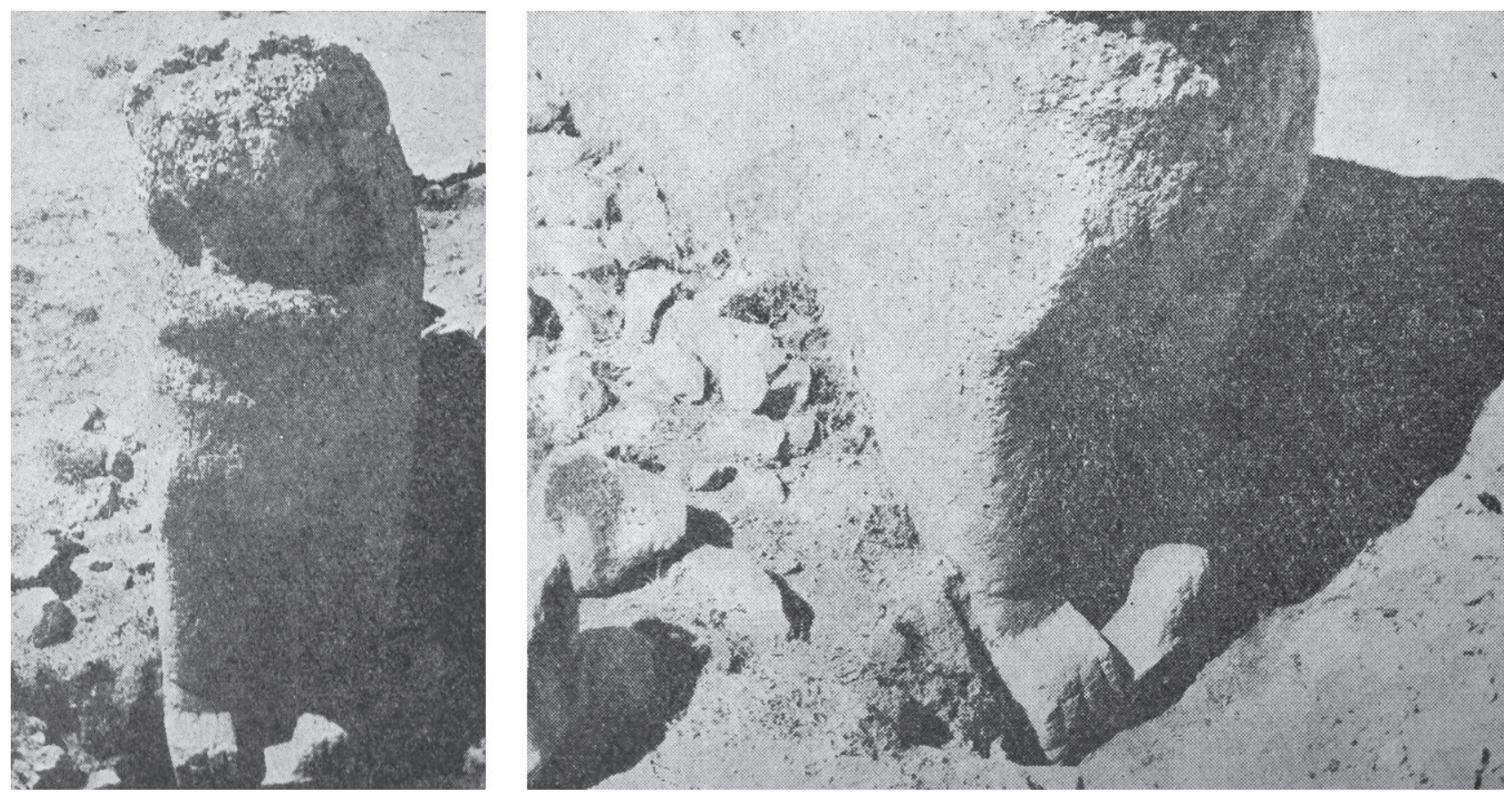

Fig. 6: Arlantaş in 1947, lion A forepaws. Adapted from: Özgüç, Özgüç 1949: 16, res. 18-19.

and softly modelled, as is especially evident in the rendering of the gentle and rounded curves of the shoulders. However, as for the forelegs, little attention has been paid to their proportions, namely that the lower parts are unnaturally thinner than the upper ones. Only the left paw of lion A is visible. Once again, this is done by rendering the four claws with thin and stylized traits, while the paw side is once again not visible. A thick tail is observable on the upper parts of the backs of both figures, disappearing between the legs and turning sideways approximately at the point where the limbs became thinner. Indeed, the faint trace of a carved tail is visible on the external side of lion A, where it sharply runs diagonally downwards with a final thickened upturned curl, maybe symbolizing the hair tuft. 
The main traits that characterize the lions from Arslantaş also recur on the Sevdiliköy one. ${ }^{4}$ The above-mentioned imbalance of rounded natural surfaces and out-of-proportion anatomical details represents the basic characteristic of this sculpture as well (Fig. 7). Moreover, the lion is thought to be a free-standing monument with its almost entirely three-dimensional shape made for a four-side view (Fig. 8). Considering its general iconographic and stylistic aspects as well as dimensions, the lion from Sevdiliköy is essentially quite identical to those from Arslantaş. The figure is slender but characterized by an unnatural triangular and static shape of the body. The head is retracted into the shoulders and shows cubic and unbalanced proportions. The shoulder muscles are once again well-defined but still characterized by rigidity and flatness.

Most of the details of the heads of the Arslantaş lions are also visible here, such as the big and protruding eyes, the wide and deep open mouth with faintly visible hanging tongue, the emphasized cheek muscles, the squared and broad nose, as well as the band that surrounds the head. In any case, it should be noted that the sculpture is better preserved than those from Arslantaş, allowing for a better analysis of some anatomic details (Fig. 9).

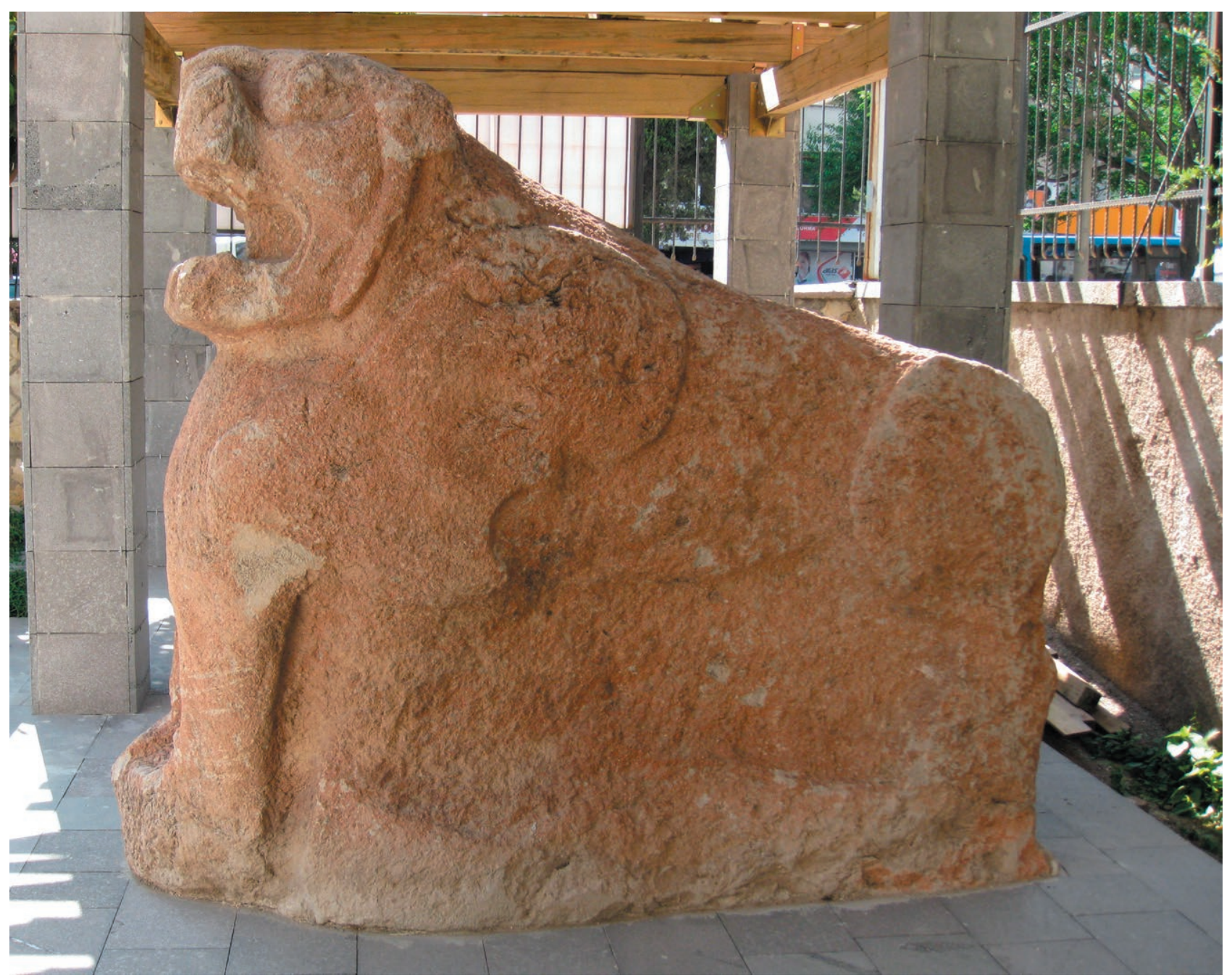

Fig. 7: The lion of Sevdiliköy in 2011. Credit: Bilgin 2021.

\footnotetext{
${ }^{4}$ The exhibited lion is made of andesite and is $2.04 \mathrm{~m}$ in height (Eralp 1995: 115).
} 

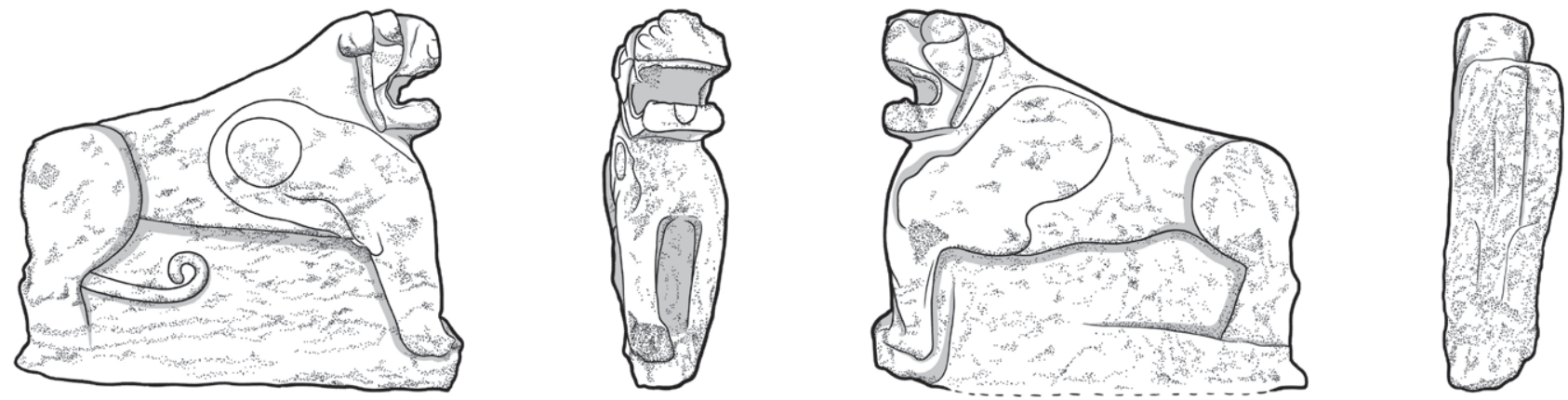

unclear delineation

shading

natural erosion and /or deliberate destruction

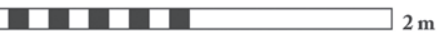

Fig. 8: The lion of Sevdiliköy. Drawings by R. Zahler based on: Eralp 1995 and Bilgin 2021.
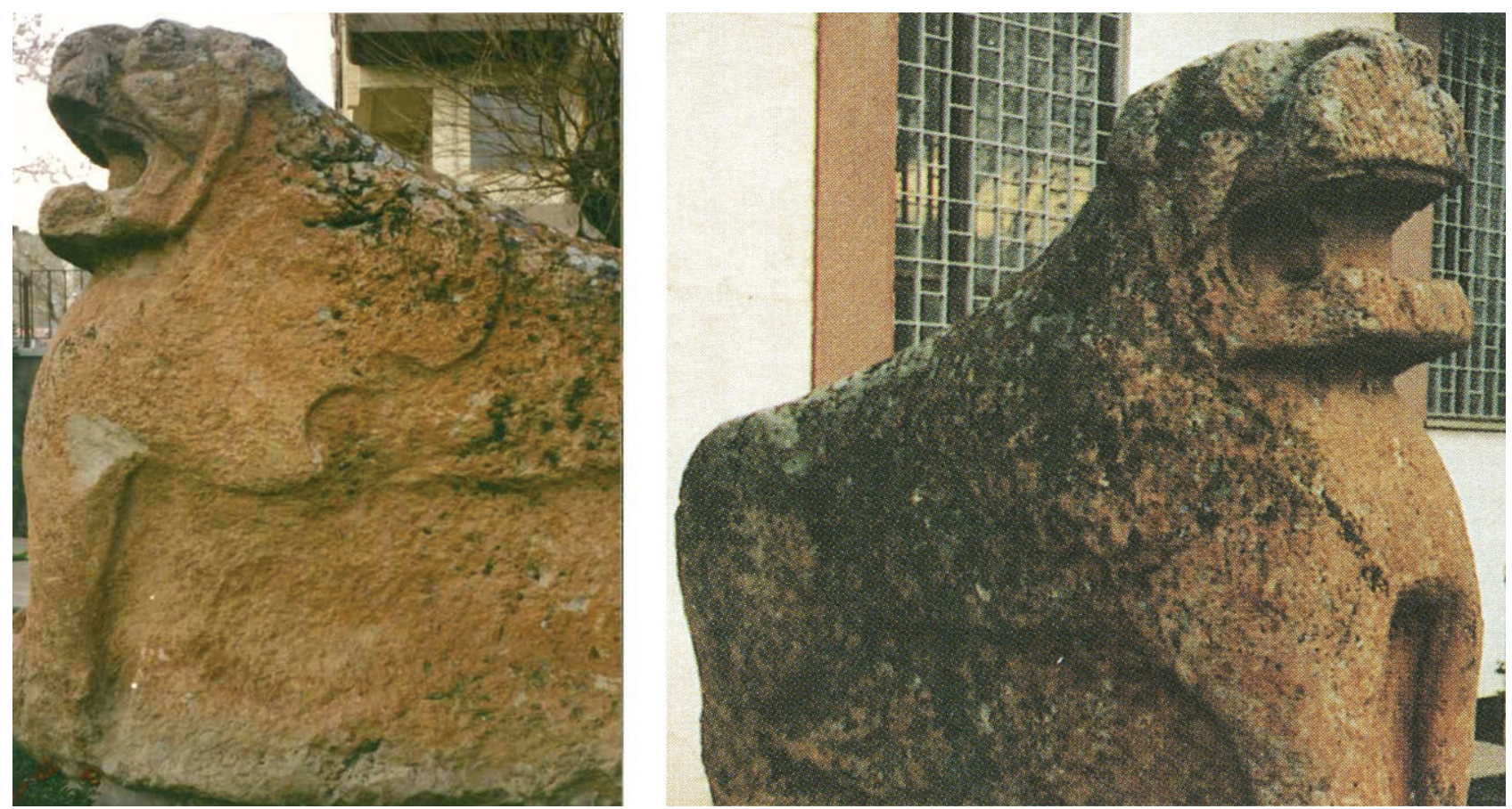

Fig. 9: The lion of Sevdiliköy in the 1990s, the foreside. Adapted from: Eralp 1995: Lev. E6, F1, courtesy of Gül Eralp Kania.

The muscles around the mouth are softly defined by a thin curved surface, while the muzzle is high, squared and pronounced. A thick tail starts from the back of the animal, disappears between its legs and appears then again on its right side running horizontally and finally turning up with a curl (Fig. 10). The ears rise up from the band that surrounds the head in the shape of two large patches. The eyes are oval-shaped and well-defined. Uncommonly, the mouth does not show any trace of fangs, but a series of fractures at its far ends let us assume that they should have been there originally. In contrast to what can be observed at Arslantaş, no trace of mane or fur is visible on the lion surface. Moreover, the sculpture entirely stands on a substructure that slightly protrudes outside the limits of the animal shape.

The forelegs are rounded and straight with the right limb slightly advanced, providing a certain idea of movement. In any case the left shoulder is definitively out of proportion, occupying a great part of the body space and being itself as long as the rest of the leg. Moreover, the joint between the upper and the lower parts of the limb is 

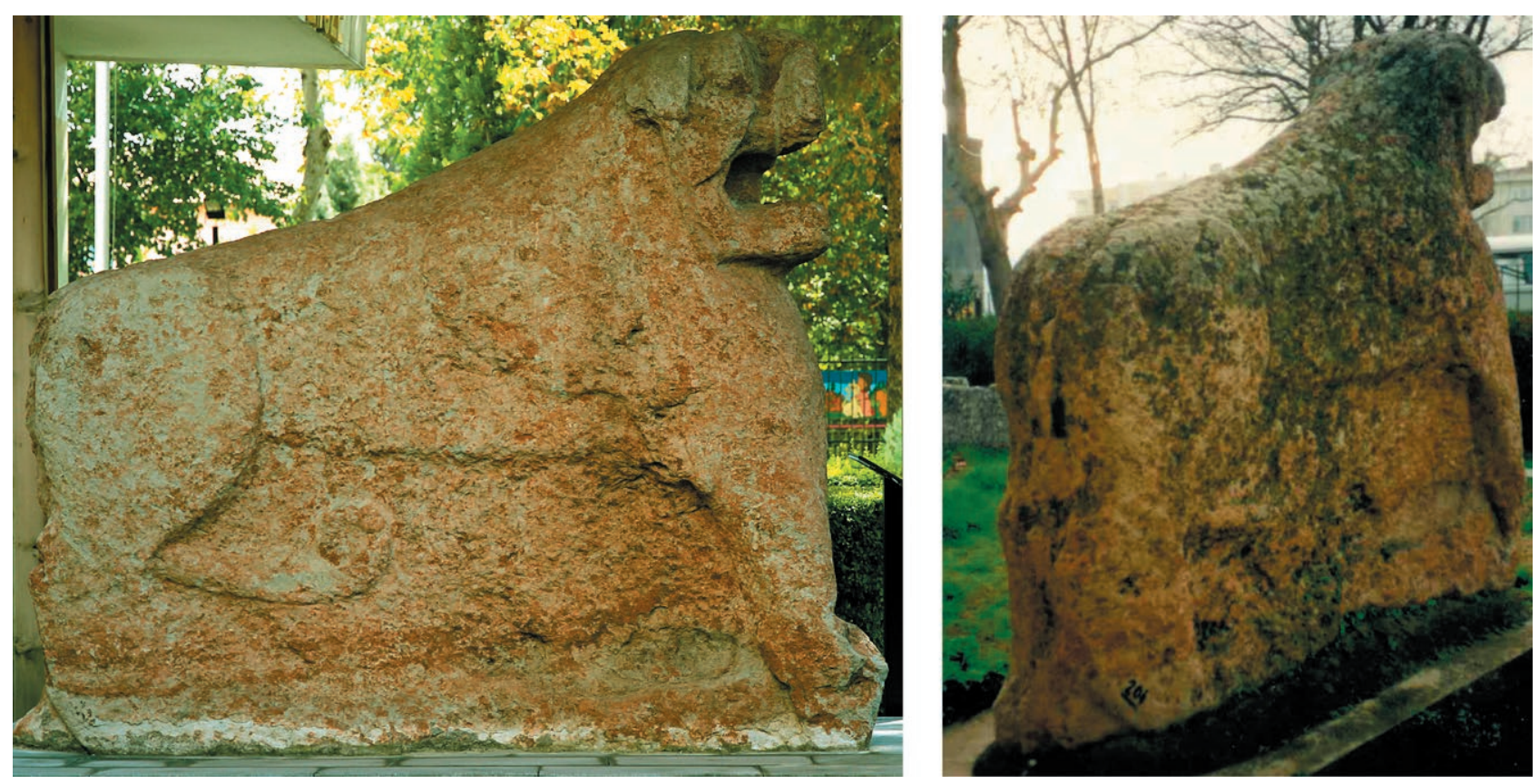

Fig. 10: The lion of Sevdiliköy, the lion' right side in 2014 (left) and back side in the 1990s (right). Left, credit: Wikimedia Commons, https://commons.wikimedia.org/wiki/File:Kahramanmaras_Museum_L\%C3\%B6we_Sevdilli.jpg, CC-BY-SA-3.0. Right, adapted from: Eralp 1995: Lev E5, F3, courtesy of Gül Eralp Kania.

once again very unnatural and sharp. Although barely detectable, the paws of the forelegs are rendered by four stylized claws visible on their upper side only. Even more unbalanced are the hind legs. First of all, the right back shoulder is longer compared to the left one, capturing almost all the space designated to the entire leg. As a result, the lower right hind leg is completely projected forwards, giving the impression that the animal is crouched on this side. The lower left leg is better proportioned, but its paw is extremely elongated, probably in an attempt to compensate for the position of the right limb. At the extremity of the left paw the faint traces of four elongated claws are again visible. Interestingly, the points where the upper and the lower hind legs join are, in both cases, naturalistically rendered by means of a small and round protrusion.

The lion from Hunu shows instead an important set of differences compared to Arslantaş and Sevdiliköy (Fig. 11). ${ }^{5}$ This is especially evident in its smaller size, as well as its rendering and design (Fig. 12). In-depth observations are difficult because the lion almost doubtlessly is both reworked and unfinished. Three different carving stages are indeed visible on the sculpture. The right backside is only roughly hewn and the front and front-right is carved with finishing details, while the entire left side is smoothed and outlined (Fig. 13).

Despite the fact that these activities are easily recognizable on the stone, the establishment of their temporal order is difficult. However, the occurrence of the different carving steps on the sculpture can hardly be explained other than as an unfinished carving process of reusing the stone block. It gives the impression that its front finished side represents either the earliest or the latest carving activity. The hammering and smoothing traces on the two sides mark instead an even later reuse that was probably never finished. With this is mind it is clear that establishing either its original or final shape is virtually impossible.

However, it is also very interesting to note that there are more than a few correspondences with Arslantaş and Sevdiliköy in some of the iconographic and stylistic details still visible on the sculpture. First of all, the upper curved outline of the stone block reproduces once again the spine and the backside of the animal. It allows the

${ }^{5}$ The lion is made of basalt and is $1.30 \mathrm{~m}$ in height and 1.60 in length (Kökten 1960: 43). 


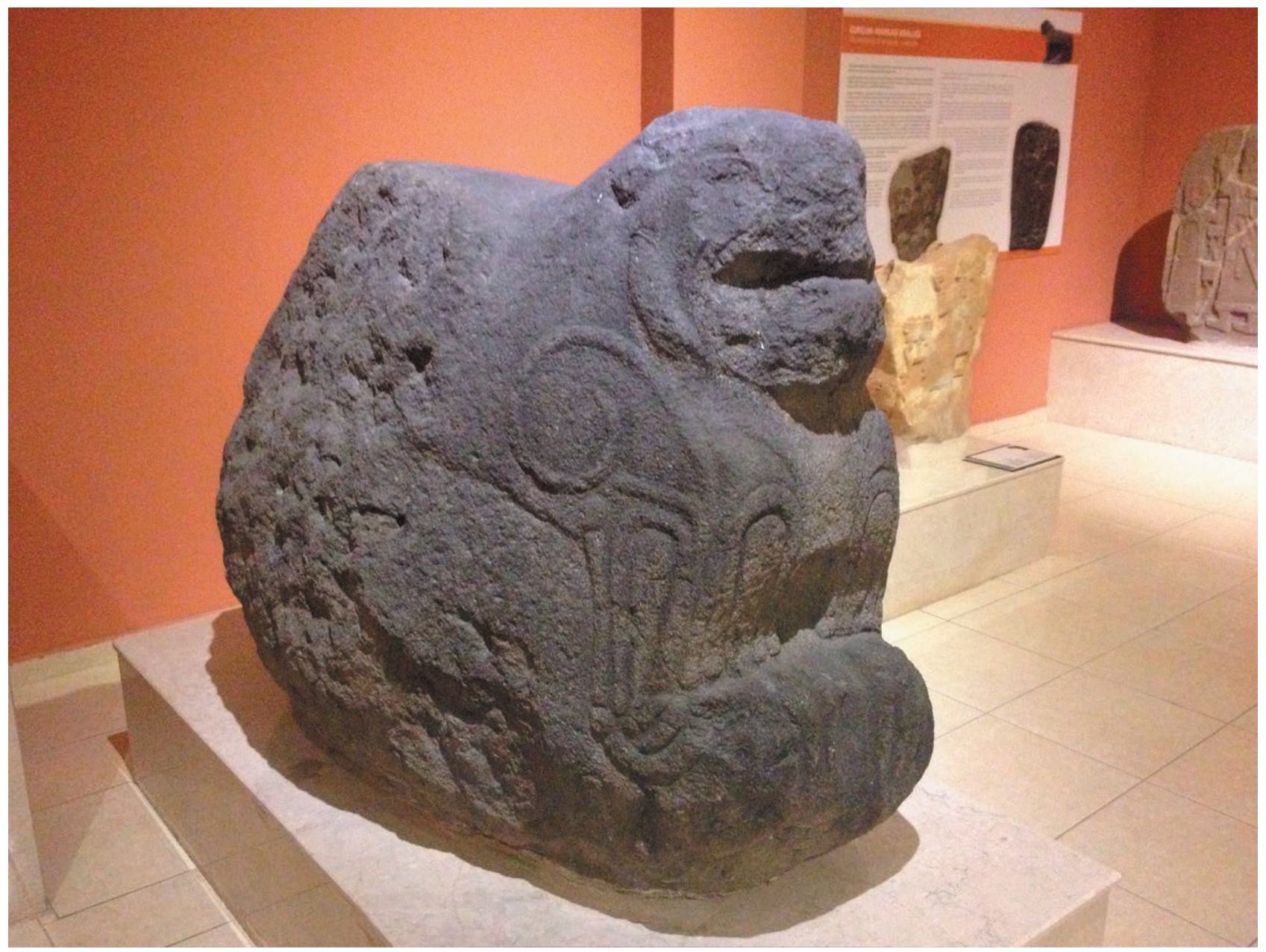

Fig. 11: The lion of Hunu in 2015. Credit: Bilgin 2021.
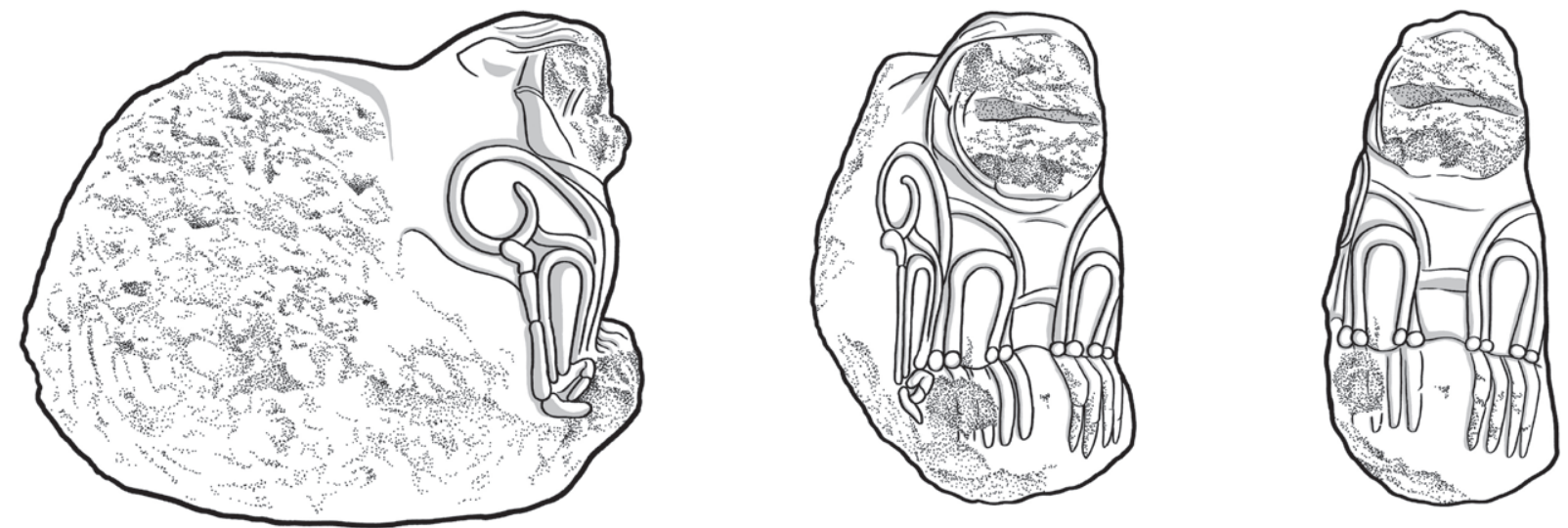

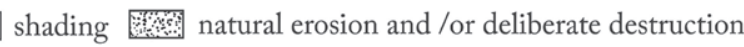
$2 \mathrm{~m}$

Fig. 12: The lion of Hunu. Drawings by R. Zahler based on: Kökten 1960 and Bilgin 2021. 


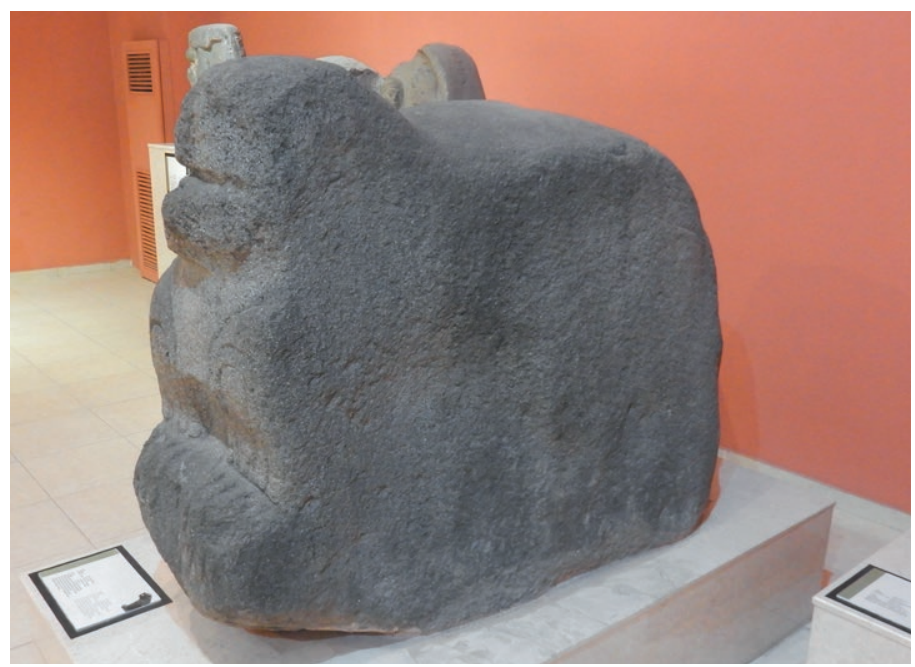

Fig. 13: The lion of Hunu in 2015, the lion' left side. Credit: Bilgin 2021.

assumption that this lion as well was not thought to be a structural element but rather a free-standing sculpture. Moreover, the general posture of the lion, with its retracted and unnatural position of the head as well as its rounded, plastically sculpted but at the same time cubic and stiff character, are very close to the other lions. Despite the fact that the front face is almost completely lost, probably erased together with the left side of the lion, interesting observations can be drawn from its right side. The head is surrounded by a curved band on which the traces of the depressions left by a small triangular retreated ear are still visible. The eye is only slightly perceptible. It was certainly wide, with its upper orbital part protruding. The mouth was also wide and open, as well as characterized by a soft line that defines its lateral muscles. Because of all these characteristics, the head of the Hunu lion can be considered very close to those of Arslantaş and Sevdiliköy.

Nonetheless, it cannot be ignored that the design of the limbs shows significant differences. First of all, their shapes are mostly carved rather than rendered in relief. The lower torso is only visible by means of a faint incised line that shapes its outline. The shoulder is defined by an unnatural spiral form, an attempt to balance anatomic details and decorative patterns. The external side of the right foreleg has a triangular shape with the muscles stressed by further incisions. The same pattern occurs on the front side of the legs. Despite the fact that their outline is softly and naturalistically defined, with incised lines that emphasize the upper shoulder curvatures, the overelaboration of the muscle details produces once again an extravagant result. The view of the lower legs is even more awkward. Indeed, this part protrudes, creating a sort of unnatural break in the front limbs and giving the idea that the animal is crouched. Moreover, this protuberance was completely designed to reproduce the animal paws, with the result that these are as long as the upper legs. Once again, the paws are defined by four elongated and slim claws.

\subsection{Comparisons}

In the wider framework of the Syro-Anatolian figurative art of the late $2^{\text {nd }}$-early $1^{\text {st }}$ millennium BC, the lions from Elbistan show on the one hand their adherence to specific artistic canons and, on the other hand, the introduction of original aspects. ${ }^{6}$

First of all, it should be noted that the lions from Arslantaş, Sevdiliköy, and Hunu are unique in their arrangement (Fig. 1). As a matter of fact, lion sculptures were usually integrated into specific structures with the intent of

${ }^{6}$ If not otherwise specified the nomenclature of the following comparisons is always based on the numeration provided by Orthmann (1971). 
guarding the gates of cities, palaces, temples or citadels (Mazzoni 2013: 470-471; Pucci 2015: 59-70). These 'proper' portal lions were indeed always sculpted on one side only, while their structural parts were left uncarved. The forelegs and the heads were protruding and three-dimensionally rendered, but the rest of the figures were intended for a lateral view with a bidimensional approach that implied the visibility of the hindlegs on the carved sides only. The sculptures from Arslantaş, Sevdiliköy, and Hunu were instead completely free-standing and three-dimensionally shaped for a four-side view. They were not meant to be integrated into a structure, rather they were 'virtual' portal lions, themselves representing a structure. A couple of similar cases can be taken into consideration. The lion from Çolakliköy, found out of its context in the namesake village, is probably the best comparable example (Tunca 1976). It was sculpted on its four sides exactly in the same manner as the Elbistan lions and its dimensions are comparable with Hunu. Nonetheless, the right-side section of the back was flattened with a rectangular hole and its rear end was squared off vertically. Hence, it should have been used with some structural purpose. Actually, this lion seems to be structurally akin to the figures adorning the entrance of the Kapara Temple-Palace at Tell Halaf (Moortgat 1955: 110-114). Indeed, the two lions of the four-bay portico were also sculpted on their four sides, serving architecturally as statue-stands of the hilani façade (Gilibert 2014: 40-44). Another all-round lion is Hama $\mathrm{C} / 1$. It is fully three-dimensionally shaped even in the part underneath the body and between the legs. Unfortunately, the lion is the result of a very invasive restoration and not a few doubts about its original design have been raised (Orthmann 1971: 102-103; Riis, Buhl 1990: 50-52).

The wide set of unfinished lions coming from quarries and workshops also show, at a first glance, similarities with the sculptures from Arslantaş and Sevdiliköy. These are especially evident for some of the standing lions from Yesemek (Duru 2012: 68-71, lev. 8-11), as well as examples from Sıkızlar, Zilfe and Demirciler (Mazzoni 1986; Mazzoni 2011: 141-143; Carter 1996: 292-293, 304-305; Konyar 2009: 178, 185-186). Actually, affinities are mostly related to their stiff posture and cubic proportions, but exact comparisons are hard to make and misleading considering their incomplete nature. In fact, a more careful analysis shows that these sculptures were always thought to be 'proper' portal lions, since they were outlined on one side only and, when visible, their hindlegs were both carved on the same side.

As mentioned, the posture of the forelegs of the lion from Hunu is very unnatural and atypical. It recalls the small, crouched lion displayed in the Gaziantep Museum, which interestingly seems to originally come from the Elbistan region as well (Balcığlu 2009). Actually, squat lions are very common in the Syro-Anatolian art, such as that visible on relief E/1 of the Herald's Wall and H/2 of the King's Gate at Karkemiš (Hogarth 1914: pl. B10a; Woolley 1952: pl. B55a). Moreover, crouched lions are frequently depicted as deity stands, as at Darende and with the stele B/4 from Malatya (Hawkins 2000: 304-305, 328, pl. 145-146, 164).

When we turn to their iconographic and stylistic details, further peculiarities emerge. The head of the lions, completely retreated into the shoulder and without any trace of neck, provides these figures with a unique posture. The upper curved outline of the body of the lions from Arslantaş and Sevdiliköy is also very uncommon. It recalls the shape of the portal lion Malatya A/2 (Dalaporte 1940: pl. XVI-XVII; Orthmann 1971: 97-98). In contrast, the back rump-shape of the lion from Hunu is more canonical and comparable with the specimens C/1-2 and C/4-5 from the Lion's Pit at Zincirli (Luschan 1902: Taf. 46-47), as well as with the portal lion Malatya A/1 (Dalaporte 1940: pl. XVIII-XXI) and the lion base Karkemiš H/11 (Woolley 1921: Pl. B21; Orthmann 1971: 41-42).

The horizontal movement of the tail of the lions from Arslantaş and Sevdiliköy is also without comparisons. Indeed, the typical Iron Age tails curl up between the legs of the animals but always moving from up to down (Akurgal 1949: 68-71). The closest examples are attested at Ain Dara, on the portal lions A/1-2 (Orthmann 1971: 58, Taf. 1a) and on the reliefs of the outer façade of the temple terrace (Abū Assāf 1990: pl. 19a, 22a). Here, the lions' tails run horizontally under the bodies of the animals but always curl down.

The mane covering the entire body of the lions from Arslantaş is also unique. Indeed, when attested, the fur covers the frontal parts around the heads of the animals only, as a proper mane, while in a few other cases it extends over the bellies of the lions (Akurgal 1949: 70-73). Moreover, at Arslantaş the pattern is also atypical. Some affinities can be seen with the leaf-shape mane of the sculptures of the Temple-Palace at Tell Halaf (Moort- 
gat 1955: 110-114, Taf. 120-121, 128) and with the overlapping irregular lozenge-shape mane of the antithetical lions on the pedestal wall relief of the cella of the Storm-God Temple at Aleppo (Gonnella et al. 2005: 108-109, Abb. 152; Kohlmeyer 2013: 522).

More affinities with the repertoire of Syro-Anatolian art can be found when we turn to the anatomic details of the lions. The head shape of the lions from Arslantaş, with their open wide mouths and protruding upper orbital eye parts, finds comparison with the figures of the Temple-Palace at Tell Halaf (Cholidis, Martin 2010: 346 354; Moortgat 1955: 113-114, Taf. 127-128). The solid and cubic form of the head of the lion from Sevdiliköy is instead very similar to those of the animals carved on reliefs B/11 and B/12 of the Outer Citadel Gate at Zincirli (Luschan 1902: Taf. 44). Moreover, its squared and large nose is close to those carved on the lion base Karkemiš H/11 (Woolley 1921: Pl. B21). The emphatic cheek muscles of Arslantaş and Sevdiliköy characterize many of the sculptures of the Herald's Wall at Karkemiš (E/3, E/4 and E/9) (Hogarth 1914: pl. B11a-b, B14b; Orthmann 1971: 31-32), as well as the relief with the antithetical lions from Aleppo (Gonnella et al. 2005: 96, 101, 108-109, Abb. 133, 141, 151-152). The small triangular and retreated ear of Hunu is also comparable with examples from the Herald's Wall at Karkemiš (E/1 and E/3) (Hogarth 1914: pl. B10a, B11a), as well as with reliefs from Aleppo (Gonnella et al. 2005: 108-109, Abb. 151-152). The big, raised ears integrated into the band around the head of Sevdiliköy recall instead the portal lions A/1-2 from Ain Dara (Orthmann 1971: Taf. 1a). Again, it should be considered that the way they hang laterally in a large patch-shape is without comparisons.

The band that surrounds the heads of the lions from Arslantaş and Sevdiliköy is quite characteristic of SyroAnatolian art. It can be seen again at the Herald's Wall at Karkemiš (E/1, E/3, E/4, E/6 and E/9) (Hogarth 1914: pl. B10a, B11a-b, B13a, B14b), as well as in the reliefs from the pedestal wall at Aleppo (Gonnella et al. 2005: 96, Abb. 133). The more protruding curve around the head of Hunu is instead more similar to those on the portal lions Malatya A/2 (Delaporte 1940: pl. XVI-XVII) and Ain Dara A/1-2 (Orthmann 1971: Taf. 1a), as well as on the lion base Karkemiš H/11(Woolley 1921: Pl. B21).

Many sculptures and reliefs present rounded and well-defined fore and back shoulders. Not in a few cases the rendering of the anatomic details is out of proportion, recalling those of Arslantaş and Sevdiliköy. This is especially visible on some of the reliefs of the Herald's Wall at Karkemiš (E/1 and E/4) (Hogarth 1914: pl. B10a, B11b) and again on the antithetical lions from Aleppo (Gonnella et al. 2005: 108-109, Abb. 152). The peculiar sharp angle that characterizes the joints of the forelegs at both Arslantaş and Sevdiliköy finds a good comparison with the unnatural posture of the lion carved on relief $\mathrm{A} / 9 \mathrm{a}$ and the bulls reproduced on reliefs $\mathrm{A} / 3$ and $\mathrm{A} / 4$ at Malatya (Delaporte 1940: pl. XIX, XXII; Orthmann 1971: 91-92). The spiral-shape of the shoulder of the lion from Hunu is however more uncommon. As a decorative element, the spiral occurs for instance on the sphinx protome Zincirli K/8 (Orthmann 1971: 73, Taf. 67b), while a pattern similar to Hunu can be seen on the bulls decorating the sculpted base from Domuztepe (Çambel 1999: 94, pl. 122-123).

The pattern made with incised lines that reproduce the muscled shape of the forelegs at Hunu is not rare in the repertoire of the Syro-Anatolian art. Comparisons can be made with the lions decorating the reliefs of the terrace of the temple at Ain Dara (Abū Assāf 1990: pl. 19a, 22a), as well as with the relief H/2 from the King's Gate at Karkemiš (Woolley 1952: pl. B55a; Orthmann 1971: 31-33).

As far as the paws of the three sets of lions is concerned, they certainly share the general characteristic of ending with elongated claws. However, only the case from Arslantaş offers the possibility of drawing specific comparisons. Interestingly, T. and N. Özgüç (1949: 63-64, Abb. 18-19), stated that when they visited the site the forepaws of lion A were visible. They describe the four claws on each paw as flat on their top, curved on the front and with some linear decorations, suggesting a very suitable comparison with the early sculptures of the Lions' Pit at Zincirli (C/1-3) (Luschan 1902: Taf. 46-47). A further association can be made with the earlier group of reliefs from Hama (Riis, Buhl 1990: 40-42, fig. 17). The back paw still visible on the internal side of lion A shows an even more stretched and slim shape of the paws that seems to be comparable with those of the lions of the Temple-Palace at Tell Halaf (Cholidis, Martin 2010: 346-354; Moortgat 1955: 110-114, Taf. 121-122, 129). 


\subsection{Style and Dating}

The lions from the Elbistan plain have never been concretely integrated into the development of the SyroAnatolian art. W. Orthmann (1971: 118) included them in his collection, saying that due to their posture they do not specifically belong to any group and because of their coherent characteristics they might all be attributed to the same workshop. Despite this, he tentatively assigned Sevdiliköy to his style II and Hunu to style III, without any specific mention of Arslantaş (Orthmann 1971: 486, 533). Before him, T. and N. Özgüç (1949: 63-64) instead proposed a dating for the lions from Arslantas to the $11^{\text {th }}$ or $12^{\text {th }}$ century BC, since they merge rounded and smoothed surfaces typical of the Hittite period with more squared details of some later sculptures. Following the same idea, G. Eralp (1995: 118-119) also agreed that both Arslantaş and Sevdiliköy belong to an early phase of Late Hittite art. In contrast, S. Mazzoni (1997: 366) considered all sets of lions from Elbistan as belonging to a consistent group of free-standing sculptures dated to the $9^{\text {th }}$ century BC, together with Havuzköy, Çolakliköy, Tell Halaf, and Hama. More recently, A. Gilibert (2015: 143) found the comparison with the sculptures from Ain Dara more suitable, setting the dating of the lions to the $11^{\text {th }}$ century BC. Moreover, V. Blanchard (2019: 191-193) considered the lions from Arslantaş and Sevdiliköy as evidence of the activities carried out across the Elbistan territory during the $12^{\text {th }}$ century $\mathrm{BC}$.

It is undeniably challenging to situate the case of the Elbistan lions within the already complex lines of development of Syro-Anatolian art. Indeed, the identification of a general development of this form of art is difficult to trace, especially in the absence of reliable contexts and considering the differences in style occurring at contemporary sites (Orthmann 2002: 153-155; Manuelli 2016: 28-29). The lions from the Elbistan plain represent a proper stylistic group without any trace of a clear internal development. This increases the difficulties of delivering an appropriate cultural and chronological assessment.

It should also be considered that the Syro-Anatolian lions have never been the focus of any detailed study, and curiously Orthmann has also not provided any specific analysis of them as individual figures. Remarkably, the most reliable and comprehensive study on the development of lion iconography and style between the end of the $2^{\text {nd }}$ and the beginning of the $1^{\text {st }}$ millennium BC is still nowadays provided by E. Akurgal (1949: 57-75). However, more recently S. Mazzoni (2000: 1046-1048; 2013: 477) has added new cases and thoughts to the topic, still confirming the arguments and the general development proposed by the Turkish scholar.

With the exception of some stylistic details, the lions from Arslantaş and Sevdiliköy are almost identical. The first shows rounded edges, soft curves and more attention to detail, i.e. the mane and the paws, while the second is more squared and solid, but in any case they are undeniably very close to each other. They can certainly be the product of the same workshop or even of the same sculptor or artist and their dating should necessarily be the same. As far as the lion from Hunu is concerned, its unfinished status creates not a few problems for its evaluation. The sculpture is clearly smaller than those from Arslantaş and Sevdiliköy, but its general arrangement and above all the carving and rendering of its head is nearly the same. Despite the fact that the design of the forelegs is clearly different, the contemporaneity of the whole group is probably the preferred assumption. Indeed, it cannot be ruled out that they all belong to the same workshop, but that the carving of the lion from Hunu followed a different path and the rendering of its finished front side was made by a different sculptor than the one responsible for Arslantaş and Sevdiliköy.

Considering that the heads of the lions from Arslantaş and Hunu are deeply damaged and that the one from Sevdiliköy is also not in perfect condition, only a few elements can be used for an appropriate dating of the sculptures. Despite the fact that the movement of the tails of the lions from Arslantaş and Sevdiliköy is unusual, it needs to be noted that tails curling up between the legs of the animals are typical of the pre-Assyrian Iron Age, while during the Assyrian period they instead start curling onto their rears (Akurgal 1949: 68-69). Concerning the distinctive mane of Arslantaş, it must be stressed that the stylized spade or leaf pattern is more typical of the Hittite lions, while it developed into a flame-shape mostly during the Iron Age (Akurgal 1949: 59; Mazzoni 2000: 1046). The soft rendering of the cheeks as well as the emphatic muscles of the necks and the shoulders also echo the Hittite imperial period, while the stiff and static posture of the figures is more characteristic of the earliest Iron Age sculptures (Özgüç, Özgüç 1949: 64). Following the same dichotomy, the small retracted ear of the lion 
from Hunu recalls Hittite prototypes, but the wide and rigid open mouth is instead closer to later examples (Orthmann 1971: 118; Akurgal 1949: 70-72). The unusual rendering of the forelegs of Hunu is certainly close to Assyrian examples, but similar patterns are already visible for instance at Ain Dara (Mazzoni 2000: 1046).

A special mention is due to the paws of the lions from Arslantaş. Unfortunately, the rendering of their lateral part, which represents one of the most distinguishing features of the lion development, is not detectable. It might be assumed that the forepaws displayed a fifth lateral crouched claw. The back paw could have also been characterized by the same pattern. Indeed, neither the schematic double-thickened claws with single spiral of the earliest Iron Age sculptures, nor the stylized multiple-spiral shape of the later ones are here reproduced (Mazzoni 2013: 477; Akurgal 1949: 68).

In general, comparisons have shown that the main set of affinities occur with the lions carved on the reliefs of the Herald's Wall at Karkemiš, as well as with those of the cella of the Storm-God Temple at Aleppo, which can now be quite confidently set at the beginning of the 10 ${ }^{\text {th }}$ century BC (Mazzoni 1997: 266-267; Gilibert 2011: 116 117). Nonetheless, further features usually associated with the continuity of the Hittite artistic traits into the earliest Iron Age sculptures are also observable. Specific comparisons have been made with the sculpted lions and the reliefs of the terrace at the Ain Dara temple, dated to the $11^{\text {th }}$ century BC (Nóvak 2012: 48; Mazzoni 2013: 473; Gilibert 2015: 143), as well as with some of the sculptures reused in the Lions Gate at Malatya, which originally belong to the $12^{\text {th }}$ century BC (Mazzoni 1997: 292; Manuelli 2019). Later parallels can also be seen in certain traits of the lions at the entrance of the Temple-Palace at Tell Halaf, for which a dating to the late $10^{\text {th }}$ century BC can be assumed (Mazzoni 2013: 480; Gilibert 2014: 36). In conclusion, comparisons allow us to confidently situate the lions from the Elbistan plain between the $11^{\text {th }}$ and the beginning of the $10^{\text {th }}$ century $\mathrm{BC}$, although an earlier dating to the $12^{\text {th }}$ or a later one to the advanced $10^{\text {th }}$ centuries $\mathrm{BC}$ cannot be fully excluded.

\section{LANDSCAPE ANALYSIS}

\subsection{Method and Aims}

As mentioned, the portal lions of Arslantaş, Sevdiliköy, and Hunu represent unique and original evidence of the cultural milieu at the beginning of the Iron Age. However, their uniqueness, as well as the absence of inscriptions and associated archaeological context, have also inevitably misled their interpretation and the reconstruction of their historical significance. Yet when these monuments are plotted on a map alongside other archaeological evidence of the Elbistan region, their positioning is tremendously evocative (Fig. 14). They are located either at the foot slopes of the surrounding towering massifs (Sevdiliköy and Hunu) or on top of the natural depression between the foothills of the Anti-Taurus and the rough mountains dividing the Ceyhan river's headwaters and the Tohma river basin (Arslantaş).

In the light of these premises, a legitimate question arises: how can their outstanding topographic prominences be used to better understand the monuments' function and historical significance? And consequently: how can we formally deal with the problem of conferring a specific significance to a place beyond our simple subjective perception?

Here we discuss how to define an explanatory formal model capable of outlining the main landscape features of the Elbistan basin and its archaeological evidence. This relies on an array of quantitative methods and techniques that are nowadays quite common in GIS Science (Tilley 1994; Llobera 2001; De Reu et al. 2013).

In order to answer basic geo-historical questions, such as 'where?' and 'why there?' (Baker 2003: 37-44), two different yet interconnected approaches contribute to defining this model. First, the archaeological spatial pattern of the Elbistan basin will be outlined in order to evaluate if the lions' positioning might share affinities and discrepancies with the distribution of settlements within the same region. Second, the function and the topographic prominence of the lions will be evaluated within Elbistan's historical mobility network, as well as in relation to the geomorphological characters of their surrounding territories. 


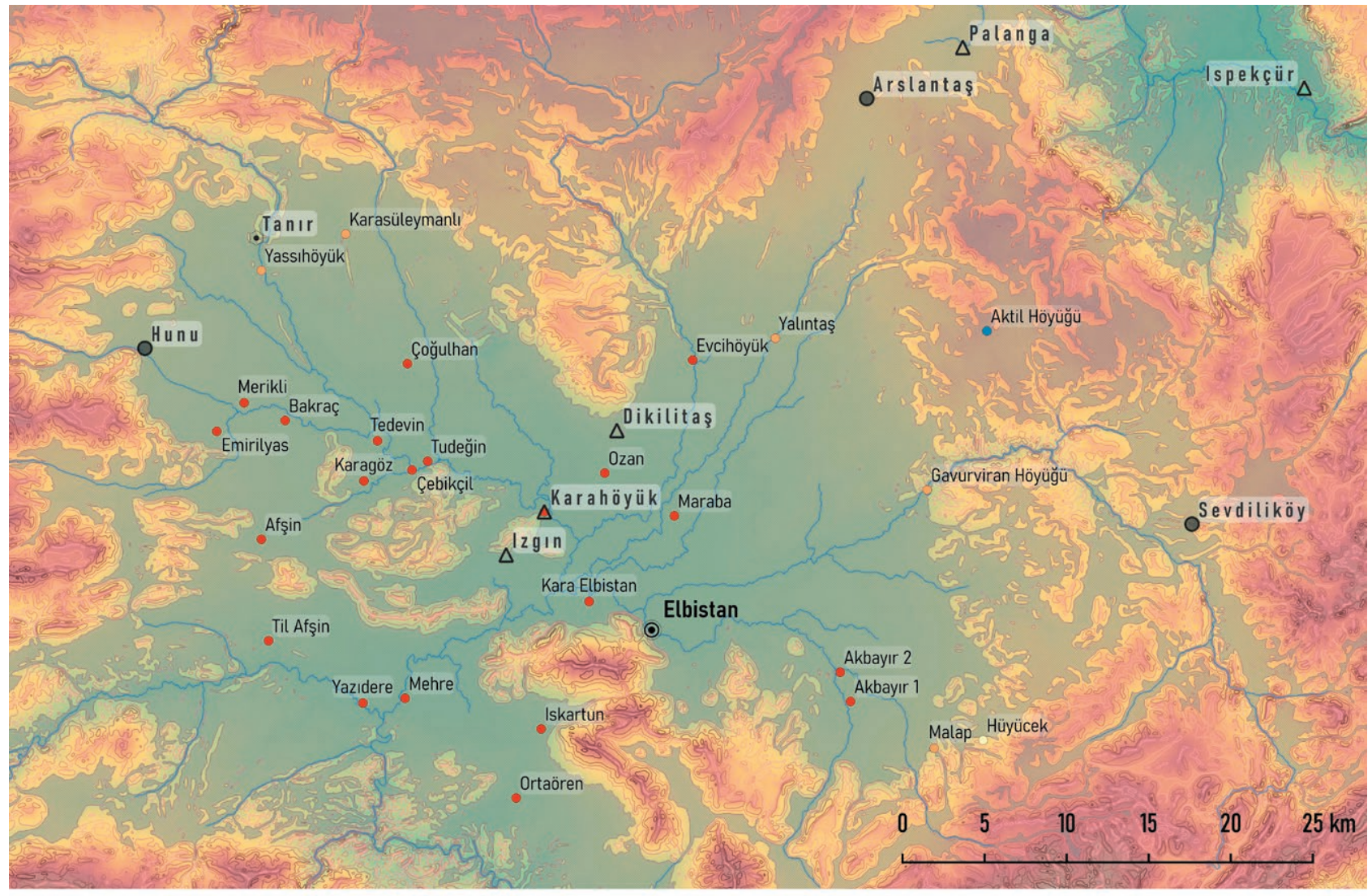

\section{Settlements (grouped by elevation)}

- 21 sites: $1117-1235$ m a.s.l.

- 5 sites: 1235 - 1353 m a.s.l.
Basin's planar surfaces

slope $<6^{\circ}$ (plains)
Monuments

- Rockinscription $\Delta$ Stele

- Stone lion

Fig. 14: Distribution of settlements in the Elbistan basin with the indication of the region's planar surfaces within the interval from $0^{\circ}$ to $6^{\circ}$ slope.

\subsection{On the Lions' Positioning ('Where?')}

The Elbistan region is an intermontane plain located in the western part of the eastern Taurides. It represents an embedded basin with a generally level floor almost entirely ringed by steep mountains reaching altitudes between 2000 and 3000 meters. The extensive ranges of the Binboğa massif enclose the western side of the plain, while the steep slopes of the Hizanlı and Nurhak mountains mark natural borders respectively to the north and to the east. The southern edge of the Elbistan plain is bordered by the Berit Dağ massif. In contrast to the rugged geomorphological nature of the surrounding mountains, the basin floor shows a high degree of uniformity. Its lower parts lie at about 1100 meters a.s.l. and, with the exclusion of the Soluk hills in the middle of the plain, the land is generally flat or gently sloping.

This sharp distinction between plain and mountains also marks a fundamental characteristic in Elbistan's long-lasting settlement history. Indeed, all the pre-classical mounds so far known seem to be located exclusively within the floor-plain (Çifçi, Greaves 2010). In order to formally support this assumption and to minimize subjective decisions, we first focus on the problem of the quantitative definition of plain areas within the study region. Despite the fact that several geomorphometric semi-automated approaches might help in recognizing such a land- 
form (e.g., r.geomorphon or Topographic Position Index), we still preferred to follow a simpler method based on empirical observations. Indeed, since the slope gradient of the terrain can be assumed as the basic criterion to outline relatively flat areas, it can be estimated that all terrains within the range between 0 and 6 degrees of slope can be safely considered plains. At first glance, this threshold value could appear subjective. It actually relies on the synthesis of different criteria that have been inferred from the survey of physical terrain conditions and comparable factors resulting from secondary literature (Veselský et al. 2015: 802-803; Di Filippo, Mori 2018: 51-53).

This allowed us to assemble a set of continuous planar surfaces derived from an SRTM DEM at 30 meters resolution through the multi-scale analysis of slope gradient geomorphometric variables. ${ }^{7}$ The results, displayed in Fig. 14, confirm that all the identified settlements do indeed lay inside the Elbistan basin flat area. Moreover, 24 of the 28 sites are located at no more than 2000 meters distance from the plain border. This limit is represented by the proper landform perimeter or by further reliefs inside the plain itself, i.e. the Soluk hills at the center of the basin.

This picture is truly revealing when we focus on the geology of the Elbistan basin, which allows us to outline an even more solid relationship between landscape and the distribution of sites. Almost all the settlements are located in geological areas characterized by alluvial plain sediments originating from recent stream beds (Fig. 15). More precisely, these settlements spread out across the geological interface between recent stream beds (Holocene fluvial sediments) and more ancient sequences of Pleistocene sediments composed of conglomerate, sandstone, siltstone, and mudstones with abundant calcretes, which generally lay at a higher elevation (Yusufoğlu 2013).
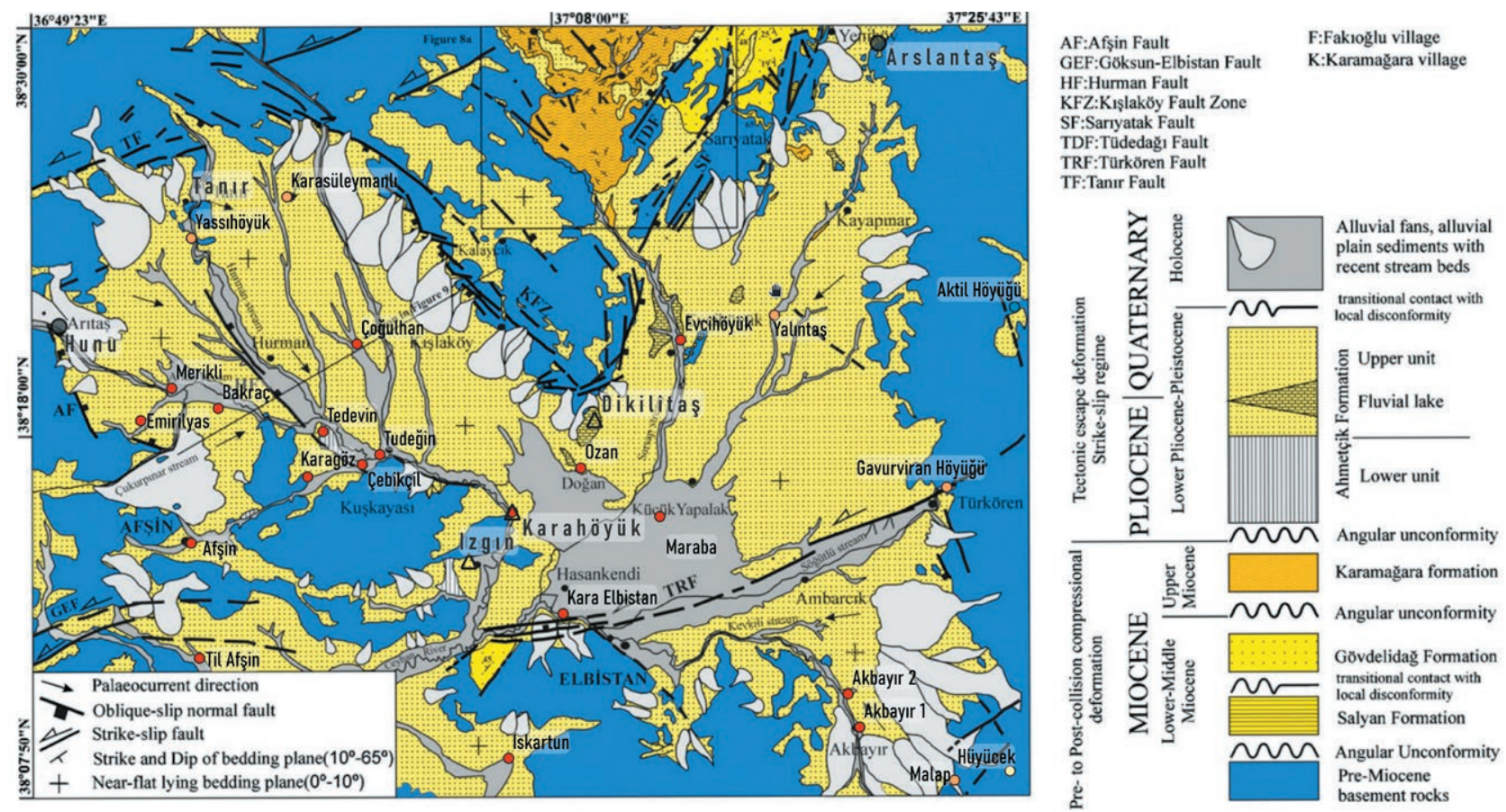

Settlements (grouped by elevation)

Monuments

- 21 sites: 1117 - 1235 m a.s.l.

1 site: $1353-1470 \mathrm{~m}$ a.s.l

- Rock inscription

$\Delta$ Stele

- Stone lion

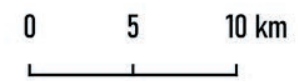

Fig. 15: Relationship between the sites' distribution and geology in the study area. Adapted from: Yusufoğlu 2013: 311, courtesy of Halil Yusufoğlu.

${ }^{7}$ GRASS GIS r.param.scale module, morphometric parameter = slope (Veselský et al. 2015: 802-803). 
This preference in the choice of settlement location can be safely considered the main feature of the sites' distribution in the Elbistan plain. The majority of the settlements (17) are located less than 300 meters apart from the geological interface formed by recent fluvial sediments cut into the more ancient Pleistocene sequences. In other words, most of the archaeological sites, and more significantly those with the longest occupation sequences, are located on natural elevations such as rocky spurs, platforms, or terraces, overlooking the underlying watercourses (e.g., Merikli, Tedevin, Til Afşin, and Yassıhöyük; cf. Brown 1967). As a consequence, there is also a noticeable relationship between the mounds' distribution and the network of watercourses (Konyar 2011; Çifçi, Greaves 2010). If one considers exclusively the permanent streams, i.e. those with significant and steady flows, 18 settlements are located at no more than 750 meters from them. Yet if the overall hydrologic system is taken into consideration, also including the minor streams, seasonal tributaries, and possibly springs, all the locations are characterized by a considerable availability of water resources.

Summing these data up, the archaeological settlements in the Elbistan basin follow a clear and coherent distribution pattern. The sites, dated from the Chalcolithic to the Iron Age, seem to be deeply influenced by the natural environment. They are located exclusively in the basin's relatively flat area, within the ecological interface characterized by gradients from 0 to 6 slope degrees. Moreover, they lie at the fringes of recent geological areas originating from fluvial accumulation of Holocene stream beds, showing a tight relationship with the network of the basin's watercourses.

In this context, the fact that the sculpted lions are located along the outer limit of Elbistan's inhabited region marks a fundamental difference from the proper settlements, and the two sets of archaeological evidence clearly follow distinctive, seemingly opposite distribution patterns.

Furthermore, the picture also helps to identify a sharp distinction between the different sets of lions. Indeed, Sevdiliköy is located at more than 16 kilometers from the closest Holocenic formation and more than 2 kilometers apart from the nearest major watercourse. A similar trend seems to be shown at Arslantaş. Despite the fact that compared to Sevdiliköy the location is closer to the basin's recent fluvial sediments (c. 3 kilometers), it still lies about 4800 meters from the steady stream. Hunu, conversely, shows some discrepancies from either Arslantaş or Sevdiliköy. The findspot of Hunu's lion (i.e., the village of Arıtaş Höyük) exactly mirrors the main features of the other settlements of the region. It is located at the intersection of the geological interface between recent stream beds and more ancient sediments (Dumankaya, Topaloğlu 2017: Fig. 7), at the western limit of the relatively flat surface of the basin (c. 1293 meters a.s.l.), and in close connection with one of the major western branches of the Hurman river. In short, it possesses all the features emphasized for the 'living' settlements rather than those shared by Arslantaş and Sevdiliköy.

The comparison of the distribution pattern of settlements and portal lions seems to show that the lack of any contemporary remains in both Arslantaş and Sevdiliköy is not due to either the dearth of archaeological research or unknown historical circumstances. Instead, it confirms that these lions are open-air monuments, intentionally conceived to be erected in the open country, without any direct relationship with any coevally inhabited center nearby.

\subsection{On the Lions' Function ('Why There?')}

The reconstruction of ancient mobility through computational techniques (i.e., the Cost Surface Analysis and the Least Cost Pathways) is nowadays routinely applied in the field of historical research (Llobera 2000; SurfaceEvans, White 2012; Polla, Verhagen 2014). Its primary purpose concerns the development of 'predictive models' that may help us to understand the nature and development of ancient road systems. Even more significantly, as a reconnaissance tool, this array of techniques provides a means by which geographically-based research problems can be examined, serving as a method of hypothesis validation (Newhard, Levine, Rutherford 2008: 99-101; Bevan 2011).

Therefore, the analysis here proposed starts by examining an aspect that has already been highlighted by the reports of travelers and explorers who crossed the Elbistan plain at the turn of the $20^{\text {th }}$ century AD: the impor- 
tance of the places where the lions were erected in the framework of an interregional communication system. For instance, Arslantaş is reported to mark the southern border of the Sivas province (Hogarth, Munro 1893: 644) or, more often, is described as a landmark along the path that leads to Derende (Ramsay, Hogarth 1893: 96; Maunsell 1902). As far as Sevdiliköy is concerned, the existence of the monument was still unknown at the time of the above-mentioned early surveys. Nonetheless, the location was already known at the end of the $19^{\text {th }}$ century $\mathrm{AD}$ as Alhazli/y and was referred to as the fundamental hub in the network of communication to the Malatya region (Ramsey 1890: 273; Maunsell 1902; Kiepert 1913). ${ }^{8}$ Interestingly, these early descriptions agree significantly, depicting the locations of these open-air monuments as liminal spaces at the fringes of the inhabited plain on crossroads along the major pathways connecting Elbistan with the Tohma Su and Malatya basins.

Taking this as a starting point, we have processed a set of computed routes through the combination of the r.walk and r.drain modules implemented in GRASS GIS. Considering the computed mobility network that joins the main Iron Age center of the plain (Karahöyük), to the coeval sites located just beyond the massifs ringing the Elbistan's basin (Meriggi 1966; Kontani et al. 2012), the peculiar location of the lion sculptures stands out (Fig. 16).9

In a general framework, Arslantaş and Sevdiliköy are both considerably far away from any plausible inner road system of the plain, which instead seems to accord quite precisely with the web of inner watercourses. In contrast, they are touched by the routes that lead from the plain to the neighboring regions.

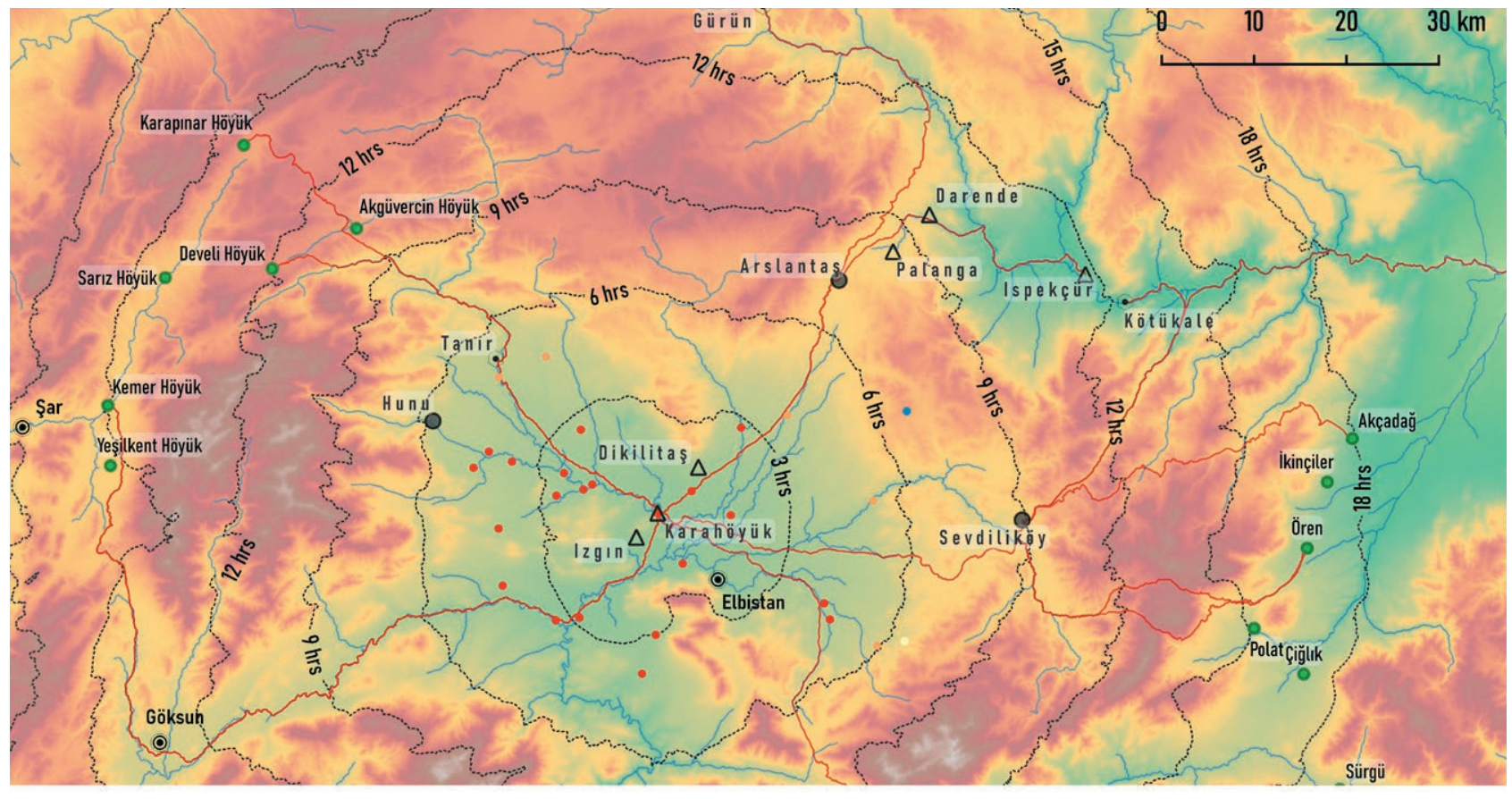

Monuments

- Rock inscription

$\Delta \quad$ Stele

- Stone lion
Least-Cost Pathways (from Karahöyük)

Computed path
Isochrones (from Karahöyük)

3 hours intervals

Fig. 16: Mobility pattern from Elbistan toward nearby basins with the indication of computed pathways and related isochrones.

\footnotetext{
8 The place-name Alhazli/y has disappeared nowadays, but was mentioned until the beginning of the $20^{\text {th }}$ century AD (Ramsey 1890 : 273; Naval Staff 1919: route 86; Maunsell 1902; Kiepert 1904-1907; 1913).

${ }^{9}$ Computed pathways have been balanced through travel times given by Sterret (1888: 299). For this region, a perfect match between real and generated pathways occurs when the spreading algorithm (r.walk) considers exclusively the rate of change of the original DEM (i.e., slope) and no friction parameters are provided.
} 
Only a few general considerations can be raised about Hunu. Its location, lying at the foot slopes of the steep Binboğa range, clearly has no close relationship with the main route leading out of the Elbistan basin. Even by forcing the algorithm parameters in order to find a suitable track across the Binboğa (e.g., from Hunu to Kemer), bypassing the massif turns out to be more convenient in terms of travel time than crossing its arduous mountain tracks.

Entering now into more detail of the locations of Arslantaş and Sevdiliköy, the perceptions of the early $20^{\text {th }}$ century travelers mentioned above seems to be fully confirmed by the computational analysis.

The lions from Sevdiliköy are located at the intersection of an array of computed routes leading eastward and crossing the Nurhak range in the direction of the plains of Sultan Suyu and Malatya. This area shows the characteristics of a proper crossroad, since it is located just before the paths which allow passage through the mountains. From Sevdiliköy three different routes allow a crossing of the Nurhak range. It is worth noting that these generated tracks correspond quite precisely to those described by ancient geographers and travelers. The first track follows a system of narrow valleys that connects Sevdiliköy to the course of the Tohma $\mathrm{Su}$, near Kötükale, from where a road is reported to reach Malatya (Ramsey 1890: 273). A second route, apparently the easier one, crosses the mountains from Alhazli (roughly corresponding to modern Sevdiliköy) and reaches Arga (modern Akçadağ), at the western foot slopes of the Malatya plain (Ramsey 1890: 273-274; Naval Staff 1919: route 86 alternative). The last track allows a crossing of the Nurhak range via the mountain pass of Ola Kaya (Sterret 1888: 299; Ramsey 1890: 273), or across the southern pass of Devrent Gedick (Naval Staff 1919: route 86). ${ }^{10}$ These variances join again descending towards the region of Polat (i.e., Ören Höyük, see Meriggi 1966). ${ }^{11}$

Moreover, the topographic relevance of Sevdiliköy in the framework of the interaction of the Elbistan plain with the eastern regions is especially visible when considering its geomorphometric variables (Fig. 17). The Sevdiliköy crossroad is precisely located at the eastern margin of the Elbistan plain, where routes running eastward converge on the banks of the Sögütlü stream, some 2 kilometers south of the rock outcrop where the lion sculptures stand. This crossroad lies within an area of small plains located at the foot slopes of the Nurhak range. Just beyond it, a natural break of the Sügültü river gives access to a system of narrow U-shaped valleys that traverses the range in its entirety. ${ }^{12}$ This 'entrance' represents the most suitable natural passageways across the mountains.

As far as Arslantaş is concerned, the site is located on the wide and almost flat saddle that links the Elbistan plain to the Tohma Su basin. From the south, this geological formation is accessed following the course of the Sarsap stream, along a route flanked by the impressive, albeit quite enigmatic, Dikilitaş monument, 'a rectangular monolith 5 meters high, set erect in a large block on a spur of the Karajik Dagh, visible from every part of the Elbistan Ovasi' (von der Osten 1930: 108 and Fig. 116). Since the discovery of the Arslantaş lions, early topographic maps (Maunsell 1902; Kiepert 1904-1907) and itinerary accounts have reported the presence of this monument and its significance as a primary node of the communication routes crossing this stretch of the Anti-Taurus. The computational analysis interestingly confirms the perception of $19^{\text {th }}$ century AD reports. It also supports the supposition that, at least during the past century, Arslantaş constituted a hub from which a set of individual roads departed to different locations into the Tohma Su basin, such as Gürün and Ispekçür (Fig. 18).

The topographic prominence of Arslantaş is defined by completely different landscape features when compared to Sevdiliköy, showing different geo-morphometric variables. These do not allow us to identify meaningful landform features that may have prompted the efforts to build the monument in that spot. A potential key to the interpretation comes instead from a further geographical description provided by an unknown explorer at the begin-

10 The Ola Kaya peak appears in the form Alaja in the map-series 'Eastern Turkey in Asia' (Maunsell 1902). Today it should be the Öğlekayasi Tepesi (N 38 12'57" E 3749'25", https://www.geonames.org/10483853/oeglekayasi-tepesi.html). The Devret Gedick modern toponym features as Derbent Dağ (N 38 11'00" E 3745'00", https://www.geonames.org/317081/derbent-dagi.html).

11 The computed routes do not stop at Polat but continue up to Oren Höyük. It is the first site with a documented Iron Age sequence after the steep descent (Meriggi 1966).

12 Two different quantitative approaches for semi-automated recognition of landform classes, r.geomorphon (Jasiewicz, Stepinski 2013) and the Topographic Position Index (Jenness 2006; De Reu et al. 2013), roughly outline the same results for the study area (Fig. 17). 


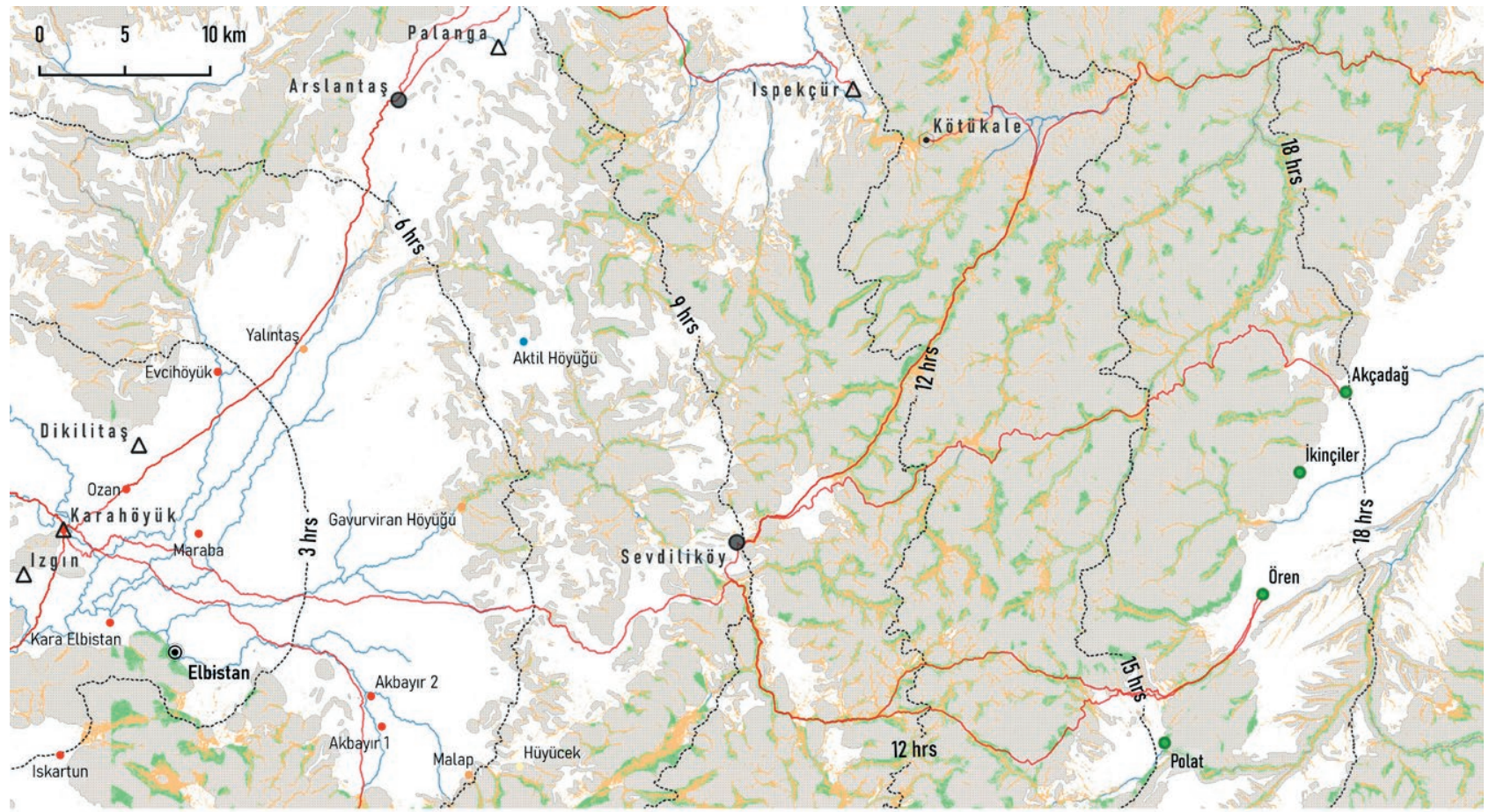

Monuments

- Rock inscription

- Stone lion

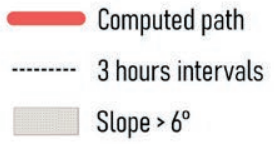

Landform classes

Valleys (r.geomorphon, landform 9)

U-shaped valleys (TPI, landform 3)

Fig. 17: Location and morphology of the 'natural passageways' through the Nurhak range.
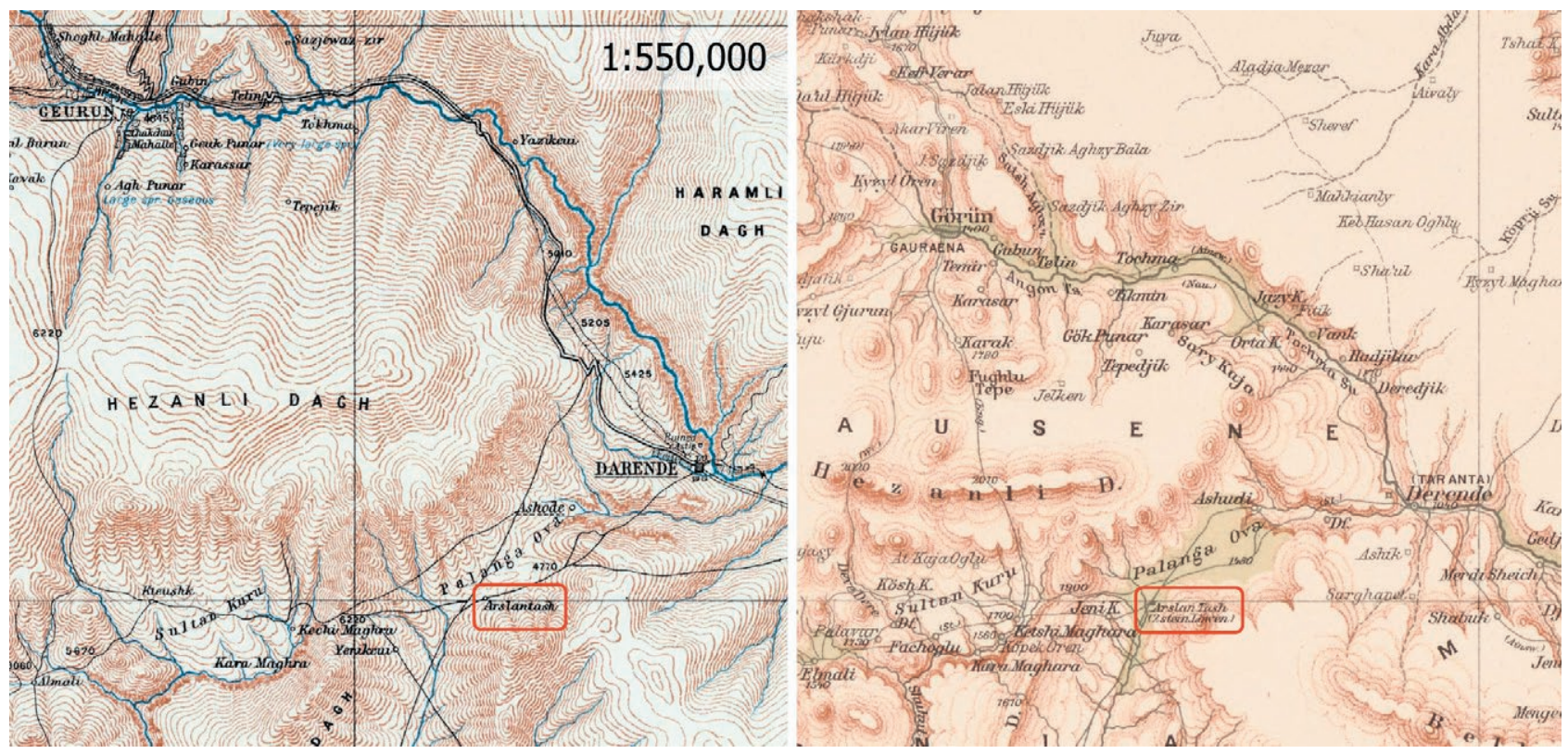

Fig. 18: The role of Arslantaş within the intermontane system of communication between the $19^{\text {th }}$ and $20^{\text {th }}$ centuries AD (approximate scale 1:550,000). Adapted from Maunsell 1902 (left) and Kiepert 1913 (right). 
ning of the $20^{\text {th }}$ century AD, which says: 'Arslan Tash, alt. 4,900 ft.; carved stone lions of Hittite origin. Here is the watershed between the Jihan and the Euphrates' (Naval Staff 1919: route 85).

On this basis, once we identify the Elbistan watershed areas (hydrologic basins) through the r.watershed analysis (GRASS GIS) and plot them on the map alongside the location of the Iron Age sites, the topographic relevance of the Arslantaş lions emerges (Fig. 19). They are located precisely on the major drainage divide between the Tohma $\mathrm{Su}$ and Ceyhan hydrological basins.

In general geographical terms, water basins are areas that act like funnels by collecting and draining off precipitation into common outlets (e.g., rivers or lakes). This implies that Arslantaş is characterized as an area that, in spite of the weather conditions, is always virtually free from significant flooding hazards. Looking at the portal lions in the context of the mobility network to and from the Elbistan plain, it is reasonable to expect that they possess such a characteristic.

Moreover, since adjacent watersheds are separated from each other by some physical features at higher elevations (i.e., ridges), this computational process allows us to highlight a piece of further significant landscape evidence. In terms of landforms, the wide saddle where Arslantaş is located is defined by such a narrow slope gradient that even the r.param.scale algorithm could not fully distinguish it from the proper plain of the basin (Fig. 14). Yet as the watershed analysis clearly indicates, Arslantaş is precisely on top of an important drainage divide, a physical feature allegedly represented by a nearly imperceptible ridge, just slightly higher than the surrounding landscape. This distinctive environmental trait must have profoundly impacted this place's significance, conferring it a power that persisted across the millennia relating to the use of surface water by local communities. As in the case of other morphologically and geologically distinct localities, such as rivers, mountain peaks, sinkholes, or springs, this area holds the geographical characteristics of a borderland. It is not surprising that at the end of the $19^{\text {th }}$ century AD, Arslantaş was still referred to as the southern edge of the Sivas province (Hogarth, Munro 1893: 644). It is highly reasonable that at the beginning of the $1^{\text {st }}$ millennium $\mathrm{BC}$, this evocative place was already similarly perceived as the northern border of the Elbistan cultural landscape.

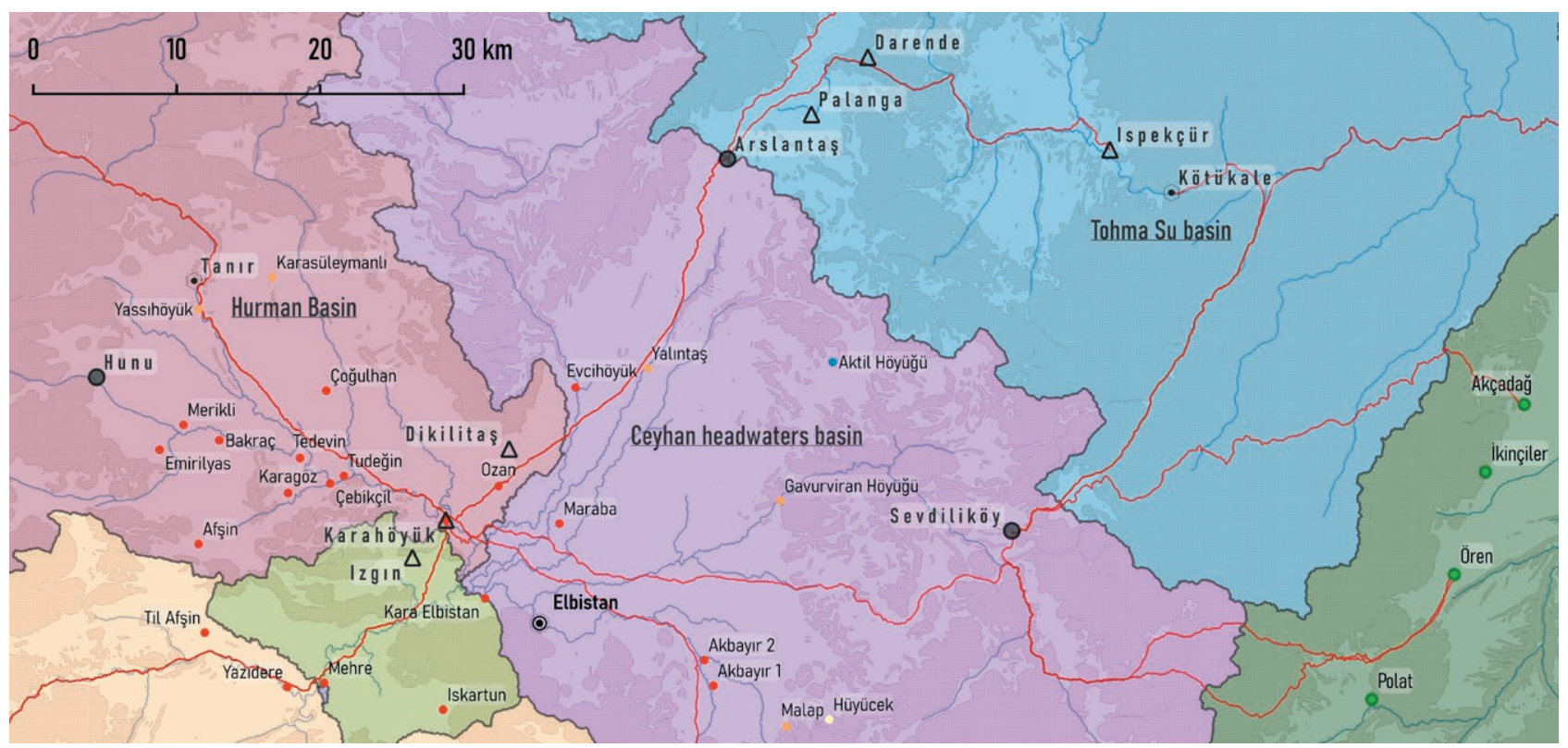

Fig. 19: The Elbistan main hydrologic basins system. 


\section{DISCUSSION: THE ROLE AND MESSAGE OF THE LIONS}

For a full understanding of the role covered by the lions of the Elbistan plain, two further factors and characteristics should be briefly considered. First, they represent a gate, if only symbolically, entailing the existence of a threshold or passage. Second, the iconographic choice of lion images is meaningful.

The symbolic role of gates in the public architecture of the Ancient Near Eastern world has been stressed by many scholars, mostly by analysing textual and iconographic sources (May 2014). In the Syro-Anatolian region of the late $2^{\text {nd }}$ and early $1^{\text {st }}$ millennium $B C$, city-gates, temple-gates or palace-gates were the main public spaces inside the settlements where ceremonies and rites were performed and the royal power displayed (Wilhelm 2011: 103105; Miller 2012; Manuelli, Mori 2016: 211, 227). This is further underlined when we consider the message conveyed by the image of lions. The link between lion iconography and ideological and religious aspects is well known since the end of the $4^{\text {th }}$ millennium BC in Mesopotamia (Peyronel 2019). This is even more evident during the Hittite period, when the lion became the embodiment of the physical, military and political power of the kingship, reinforcing the relationship between the deities and the king (Collins 1998).

In this context, the monumental guardians placed at the gates of the Hittite capital, and later wholesale adopted by the Neo-Hittite kingdoms, stood as proper symbols of the royal power (Collins 2004: 84; Pucci 2015: 62-63). They represented the subjugation of the wild world by the royalty and the town. As boundaries between the savage nature and the cities, their passage entailed the act of coming under the care of the gods and the control of the rulers (Mazzoni 1997: 294-295). The fact that these spaces were guarded by lions implied that in passing these figures one switched from being threatened by them to being protected by the self-same guardians, having moved from outside, i.e. the place of confrontation and threat, to the inside, i.e. the space the lions dominated and protected (Strawn 2001: 315-316).

Despite the 'virtual' nature of the portal lions from the Elbistan plain, and the fact that they are not concretely associated with any city, citadel, palace or temple gates, the message behind their erection could not have been any different.

The landscape analysis proposed here has also allowed us a better evaluation of this message, demonstrating that the position of the lions is not random. Their locations share all the earmarks of liminal spaces, borderlands, places of significance within the contemporary geographical perception, where the hubs of the interregional communication network intersected prominent features of the physical landscape. It is therefore not surprising that these passages were shaped into the form of open-air monumental gateways, thus blending the concepts of threshold and border alike.

The Arlantaş lions were located in the open country, in a highly strategic position. This location corresponds to the highest spot of the plateau where a set of interregional routes converges, on the natural border formed by the drainage divide between the major hydrological basins of the Tohma Su and Ceyhan. Likewise, the lions from Sevdiliköy have been erected in an area of great topographic prominence, corresponding to the eastern margin of the Elbistan plain, on a natural borderland that allows monitoring of the entrance of the pathways to and from Malatya. Interestingly, the inhabitants of the Turko-Kurdish community of the Sevdili village refer to the outcrop where the lions have been found with the toponym Kürki Kapr, which they assume means 'the gate of the mountain'. 13

As far as the Hunu lion is concerned, the fact that the sculpture comes from a site where only Roman remains have been discovered cannot be neglected (Dumankaya, Topaloğlu 2017: 291). Considering that the lion has certainly been reused, it seems highly reasonable to state that Arıtaş Höyük does not represent its primary archaeological context, rather the sculpture was displaced there in antiquity. It is in any case clear that its original location could not be far away from the site of discovery, leading to the assumption that the lion was positioned, probably together with a second sculpture, on a spot which gave access to the Elbistan territory from the west in the vicinity of Tanır or Afşin.

\footnotetext{
${ }^{13}$ Actually, while kapı is the common Turkish word for 'gate', the origin of kürki should probably be traced back to the Armenian term kürk/gürk which means 'statue' or 'idol' (Scheinhardt 1979). It leads to the equally fascinating meaning 'the gate of the statue/idol'.
} 
In a wider context, the process of displaying political and ideological power through the erection of landscape stone monuments was already fully established in Anatolia during the Hittite imperial period (Glatz 2021: 158174). In this context, rock sculptures and inscriptions were located in geologically evocative places and served the specific purpose of establishing colonial claims to borderland territories (Harmanşah 2017: 40-43).

During the Iron Age, a proliferation of stone monumental art is instead attested especially through the architectural decoration of outer facades and gates as well as the innermost spaces of the temples. These monuments were marked by a strong continuity with the Hittite prototypes, revealing the intent of the new ruling classes to adhere to an already codified idea of political power (Mazzoni 2013: 472-473; Feldman 2014: 67-72). As a matter of fact, with the breakdown of the Hittite supremacy, the disputes over the inner frontiers ceased and the appropriation of places of power was only partially resumed by the elites of the newly created Iron Age regional states (Harmanşah 2011: 57-61). Indeed, the free-standing lions of the Elbistan plain follow new and original trajectories compared to the ancestral heritage of the Hittite Empire. They follow a uniform line of development evidenced by the adoption of the same uninscribed figurative repertoire, which indicates a program conceived as a coherent whole. Moreover, if during the Late Bronze Age places with strong, distinct geological traits such as sinkholes, springs, mountain peaks, caves, or rock outcrops were preferred, the new program overturns this convention in favor of new locations whose significance was embedded in the physical features of the landscape itself as well as emphasized by the presence of specific networks of communication.

Considering the 'virtual' nature of the gates guarded by protecting figures and the fact that they were always erected at important road junctions, the interpretation of the lions of the Elbistan plain as proper boundary monuments, instead of simple landmarks, seems to be highly reasonable. The concept does not of course imply the adoption of a modern notion of border, in the sense of an imagined cartographic feature embracing a finite, abstract, and quantifiable geo-political entity (Harmanşah 2017: 38-40). Indeed, they were not necessarily thought to be placed along a line on a map separating two different controlled and organized areas; rather they marked important places within the cultural landscape, entailing a deep knowledge and awareness of the territory.

In the light of this, an interesting parallel can be found, even on a smaller scale, with the case of the early NeoAssyrian expansion that preceded the provincialization period of the $8^{\text {th }}$ century BC. This phenomenon was boldly outlined by M. Liverani (1988), following the assumption that the Assyrian territorial control of fringe zones initially did not spread systematically and uniformly (the 'oil-stain' paradigm), but rather was based on the control of a host of communication nodes ordered into a network system. The Assyrians' repeated campaigns then had the purpose of either thickening the meshes of this pre-existing network or setting up further branches of the system at a greater distance. Despite the obvious differences, it might be speculated that the monumentalization of some significant places in the Elbistan plain may represent an analogous attempt at thickening the webs of a pre-existing road system, the borders of which were not outlined by imagined cartographic features and finite geo-political spaces.

With this in mind, a final obvious question arises: how and by whom were these lions erected? There can be no doubt that these sculptures were made by skilled stonemasons and sculptors. At the same time, it goes without saying that quarrying, sculpting and transporting the rough-hewed blocks, as well as performing their final carving and positioning, required a considerable manpower (Seeher 2009: 120-125; Summers, Özel 2012: 515-516). Hence, it is hard not to think that this work was organized and executed under the auspices of a certain prominent political power.

In conclusion, two main hypotheses can be discussed in this regard. Considering their dating, it can be supposed that the lions represent either the evidence of the existence of an independent local power in the $12^{\text {th }}$ century $\mathrm{BC}$ or the consequence of the expansion of the kingdom of Malizi after its conquest of the Elbistan region from the $c .11^{\text {th }}$ century BC.

\section{HISTORICAL PERSPECTIVES}

The role of the Elbistan plain in the political scenario of the last centuries of the $2^{\text {nd }}$ millennium $\mathrm{BC}$ is generally considered, by the scholarship, strictly connected to the issue concerning the genealogical line of the 'Great 
King' Ir-Tešub, named on the stele found at the site Karahöyük (Özgüç, Özgüç 1949: 69-72). Paleographically, this dates to sometimes in the $12^{\text {th }}$ century $\mathrm{BC}$, since it shows similarities with the late- $13^{\text {th }}$ century $\mathrm{BC}$ inscriptions known from the southern Anatolian plateau. This lead scholars to assume a derivation of Ir-Tešub from the ruling dynasty at Tarhuuntašša (Hawkins 2000: 287-289; Hawkins, Weeden 2016: 10-11; Hawkins, Weeden 2017: 288-289). On the other hand, many arguments have also recently been raised to support a possible association of this ruler with the genealogy of kings of Karkemiš (Giusfredi 2010: 41-43; Harmanşah 2011: 65-69; Bryce 2012: 85-87; Simon 2013: 824-826).

It is noteworthy that scholars working on this topic have almost exclusively focused their attention on understanding which cultural or political entity, i.e. Tarhuntašša or Karkemiš, might have indirectly shown its power through this monument, entailing an influence or control over the Elbistan plain during the $12^{\text {th }}$ century BC. But the Karahöyük stele also testifies to the irrefutable existence of a local authority during this period. The inscription is dedicated to the Storm God of the land POCULUM by the local ruler Armananis, called the 'Lord of the Pithos-Men', and it commemorates the visit into this territory by the above-mentioned 'Great King', further describing the condition of the land and the donation of cities at the time of this event (Hawkins 2000: 288-295).

The stele was found during the one-year intensive investigation conducted at the Elbistan-Karahöyük settlement in 1947 (Özgüç, Özgüç 1949: 66-72). It was erected in a large open area and found in association with ash deposits and animal bones, leading to the interpretation that this was a public space characterized by cult activities and feastings (Harmanşah 2011: 65-68). ${ }^{14}$ Remarkably, the hieroglyphic Luwian signs POCULUM. PES.L.67 (REGIO) carved on the stele designate, without any doubt, the land of Elbistan and probably the city of Karahöyük itself, but the reading of this toponym is completely unknown (Hawkins, Weeden 2017: 289). As mentioned, the supposition that Karahöyük was the epicenter of a political entity based in the Elbistan territory is further supported by the evidence that the site stands out as the single largest documented mound in the whole region (Çifçi, Greaves 2010: 93).

The presence of the stele at the site as well as its dating, context of discovery and subject support the presence of a local authority in this region during the $12^{\text {th }}$ century BC with its capital at Karahöyük. With this is mind, the lion sculptures positioned at the borders of the Elbistan plain can certainly represent material evidence of this political power, marking the access to and from its territory. This is also supported by the fact that, as mentioned, the lions show a proper style of their own and are marked by some specific characteristics that have been not observed so far in any other of the renowned Syro-Anatolian sculptural cycles.

Alternatively, a further although remote possibility is to associate the erection of the lions with the events that affected the nearby kingdom of Malizi/Melid (Hawkins 2000: 282-329). The latter had its capital at the site of Arslantepe and its domain extending to the Malatya plain and the surrounding western valleys, north-eastward of Elbistan (Di Filippo, Mori 2019). Two quite similar bas-reliefs brought to light at Arslantepe and both dated to the $12^{\text {th }}$ century BC, i.e. MALATYA 9 and MALATYA 10, respectively show the Storm God of the city POCULUM and of the city Malizi receiving libations (Hawkins 2000: 320-322; Hawkins, Weeden 2017: 289; Manuelli 2019). The fact that the Storm God of the city POCULUM, which most probably corresponds to Karahöyük itself, was worshiped by a local ruler of the kingdom of Malizi on an official monument found in its capital is of course remarkable. It entails on the one hand the relevance that the city of Karahöyük and its territory had in the scenario of the Syro-Anatolian states at the beginning of the Iron Age, and on the other hand the strong cultural, religious, and political relationships linking the regions of Elbistan and Malatya.

The so-called stele from Izgin shows instead how things had already changed during the $11^{\text {th }}$ century BC. It has been found reused as a headstone in the cemetery of the namesake village, ca. $2 \mathrm{~km}$ southwest of Karahöyük itself. It describes the extension of the borders of the kingdom of Malizi, celebrating the building of new cities and the settlement of people by a local ruler called Taras (Hawkins 2000: 314-318). Considering its location it seems

\footnotetext{
${ }^{14}$ Despite providing new important data about the Iron Age occupation at the site, the new round of investigations conducted at Elbistan-Karahöyük since 2015 have not yet supplied specific information related to the context of discovery of the stele (Uysal, Çifçi 2019: 411-412).
} 
quite obvious that the stele commemorates the colonization and annexation of the Elbistan region into the Malizi realm (Alparslan 2017: 214; Hawkins, Weeden 2017: 289). The perpetuation of this relationship, or at least the fact that from time to time the kingdom of Malizi extended its domain into this region, is testified by the later inscription from Tanır. Located on a natural rock in proximity to a spring source and along an important pass that connects the Elbistan plain to the west, the inscription, tentatively dated to the $9^{\text {th }}-8^{\text {th }}$ century $\mathrm{BC}$, mentions the name of the city Malizi and contains a badly preserved group of signs probably indicating the name of one of its rulers (Doğan-Alparslan, Alparslan 2013).

In summary, despite the fact that it fails to provide an adequate historical context and explanation for the uniqueness of this phenomenon, the hypothesis that the lions erected around the Elbistan plain were a manifestation of the control exerted by the kingdom of Malizi over this territory from the $11^{\text {th }}$ century $\mathrm{BC}$ onwards cannot be completely excluded.

The fact that the sculptures show only few iconographic and stylistic similarities with the set of lions' representations known from Arslantepe can certainly suggest the existence of some more provincial production, as well as the employment of different craftsmen and workshops. Indeed, differences in iconographic models and details are in general recognizable when the images carved on the reliefs from Arslantepe are compared with contemporary artworks visible on the monuments coming from the territory around the site, such as Ispekçür and Darende (Poli 2008: 258-264).

To conclude, there are more than a few points concerning the fascinating phenomenon of the free-standing lions of the Elbistan plain that still need further explanation. However, this study has established their prominence and uniqueness within the artistic scenario of the Syro-Anatolian world of the late- $2^{\text {nd }}$ and early- $1^{\text {st }}$ millennium BC, showing their important role as boundary monuments marking essential places of the cultural landscape. Moreover, the analysis has clearly demonstrated how computational spatial models can efficiently be applied to iconographic and stylistic aspects in order to provide fresh new data that help to answer complex and unsolved archaeological and historical questions.

\section{ACKNOWLEDGMENTS}

We are deeply thankful to Tayfun Bilgin for having given us the permit to include in this article photographs from his archive of Arlantaş, Sevdiliköy, and Hunu (www.hittitemonuments.com, v. 1.72). We are equally indebted to Gül Eralp Kania for having allowed us to use the original pictures of her study on Sevdiliköy, and to Halil Yusufoğlu for the use of the map reproduced at Fig. 15. Special appreciation is also due to the John Henry Haynes archive of the Special Collections of the Fine Arts Library at Harvard University for the permit to publish the photograph reproduced at Fig. 1. We are grateful to Rana Zaher for having accepted to and succeeded in drawing the lions from available published material. For their help and precious advice offered during several phases of this study, we would like to thank Metin Batıhan, Elizabeth Carter, Ali Çifçi, Valentina D’Amico, Christian W. Hess and Mehmet Usta. Part of this research has been realized in the framework of the project 'Beyond the Crisis' funded by the German Research Foundation (DFG project \#324049112). Francesco Di Filippo wrote the landscape analysis and Federico Manuelli the part on iconography and style, both authors contributed to writing the introduction, the discussion, and the conclusions. Maps have been generated by Francesco Di Filippo using QGIS.

\section{BIBLIOGRAPHY}

Abū Assāf A. 1990, Der Tempel von 'Ain Dara (Damaszener Forschungen 3), Mainz am Rhein, Verlag Philipp von Zabern.

Akurgal E. 1949, Späthethitische Bildkunst, Ankara, Archäologisches Institut der Universität.

Alparslan M. 2017, The East: Upper Land, Išuwa-Malitiya, Azzi-Hayaša Philology, in M. Weeden, L. Z. Ullmann (eds), Hittite Landscape and Geography, Leiden-Boston, Brill: 209-218 
Baker A. R. H. 2003, Geography and History, Cambridge, Cambridge University Press.

Balcıoğlu B. 2009, Gaziantep Arkeoloji Müzesi Geç Hitit Dönemi Taş Eserleri, Gaziantep, Gaziantep Arkeoloji Müzesi.

Bilgin T. 2021, Hittite Monuments, v. 1.72, http://www.hittitemonuments.com/ (retrieved on 2021-03-03).

Blanchard V. 2019, Arslantepe, capitale du royaume de Malizi/Melid, in V. Blanchard (ed), Royaumes oubliés de l'empire hittite aux araméens, Paris, Lienart: 186-203.

Bevan A. 2011, Computational Models for Understanding Movement and Territory, in V. Mayoral Herrera, S. Celestino Pérez (eds), Tecnologías de Información Geográfica y Análisis Arqueológico Del Territorio: Actas Del V Simposio Internacional de Arqueología de Mérida, Mérida, Consejo Superior de Investigaciones Científicas: 383394.

Brown G. H. 1967, Prehistoric Pottery from the Antitaurus, Anatolian Studies 17: 123-164.

Bryce T. R. 2012, The World of the Neo-Hittite Kingdoms: a political and military history, Oxford-New York, Oxford University Press.

Carter E. 1996, The Kahramanmaraş Archaeological Survey Project: A Preliminary Report On the 1994 Season, Araştırma Sonuçları Toplantısı 13: 289-306.

Çambel H. 1999, Corpus of Hieroglyphic Luwian Inscriptions, Vol. 2: Karatepe-Aslantaş, Berlin, Walter de Gruyter.

Charles B. B. 1911, Hittite inscriptions; certain newly discovered inscriptions, together with revised copies of a number of hitherto known and still in situ, representing a portion of the results of the Cornell expedition to Asia Minor and the Assyro-Babylonian Orient, by Benson Brush Charles, Ithaca, La Vergne.

Cholidis M., Martin L. 2010, Tell Halaf V. Im Krieg zerstörte Denkmäler und Ibre Restaurierung, Berlin, De Gruyter.

Çifçi A., Greaves A. M. 2010, Settlement Patterns in the Second and First Millennia BC Elbistan Plain, Anatolica 36: 89-110.

Collins B. J. 1998, Hattušili I, The Lion King, Journal of Cuneiform Studies 50: 15-20.

Collins B. J. 2004, The Politics of Hittite Religious Iconography, in M. Hutter, S. Hutter-Braunsar (eds), Offizielle Religion, lokale Kulte und individuelle Religiosität: Akten des religionsgeschichtlichen Symposiums "Kleinasien und angrenzende Gebiete vom Beginn des 2. Bis zur Mitte des 1. Jahrtausends v. Chr." (Bonn, 20.-22. Februar 2003) (AOAT 318), Münster, Ugarit-Verlag: 83-115.

Delaporte L. 1940, Malatya: fouilles de la mission archéologique française. Arslantepe, La Porte des Lions, Paris, De Boccard.

De Reu J., Bourgeois J., Bats M., Zwertvaegher A., Gelorini V., De Smedt Ph., Chu W., Antrop M., De Maeyer Ph., Finke P., Van Meirvenne M., Verniers J., Crombé Ph. 2013, Application of the topographic position index to heterogeneous landscapes, Geomorphology 186: 39-49.

Di Filippo F., Mori L. 2018, How Difficult? Mountain Roads and Pathways Reaching Ancient Melid (Malatya) in South-Eastern Anatolia: A Reconsideration, Studi Miceneo ed Egeo-Anatolici NS 4: 41-62.

Di Filippo F., Mori L. 2019, The Malatya Plain in the Network of Interregional Relations in the Late Bronze and Iron Ages, in N. Durak, M. Frangipane (eds), Arslantepe. Proceedings of the I. International Archaeology Symposium, Malatya, İnönü University Press: 173-184.

Doğan-Alparslan M., Alparslan M. 2013, A New Luwian Rock Inscription from Kahramanmaraş, in A. Mouton, I. Rutherford, I. Yakubovich (eds), Luwian Identities. Culture, Language and Religion Between Anatolia and the Aegean, Leiden-Boston, Brill: 215-232.

Dumankaya O., Topaloğlu Y. 2017, Kahramanmaraş Afşin ve Elbistan Ilçeleri 2016 Yılı Yüzey Araştırması, Araştirma Sonuçları Toplantısı 35: 285-310.

Duru R. 2012, Yesemek. Eski Önasya Dünyası'nın en büyük heykel alteyesi, Gaziantep: Gaziantep Büyükşehir Belediyesi Yayınları.

Eralp G. 1995, Sevdiliköy Geç Hitit Aslanı, in A. Erkanal, H. Erkanal, H. Huryilmaz, A. T. Okse, N. Cinardali, S. Gunel, H. Tekin, B. Uysal, D. Yalcikli (eds), In memoriam I. Metin Akyurt, Bahattin Devam ani kitabi: eski yakin dogu kültürleri üzerine incelemeler, İstanbul, Arkeoloji ve Sanat Yayınları: 115-120. 
Feldman M. H. 2014, Communities of Style: Portable Luxury Arts, Identity and Collective Memory in the Iron Age Levant, Chicago, University of Chicago Press.

Gilibert A. 2011, Syro-Hittite Monumental Art and the Archaeology of Performance. The Stone Reliefs at Carchemish and Zincirli in the Earlier First Millennium BCE, Berlin-New York, De Gruyter.

Gilibert A. 2014, Death, Amusement and the City: Civic Spectacles and the Theatre Palace of Kapara, King of Gūzanā, KASKAL 10: 35-68.

Gilibert A. 2015, Religion and Propaganda under the Great Kings of Karkemiš, in A. D’Agostino, V. Orsi, G. Torri (eds), Sacred Landscape of Hittites and Luwians: proceedings of the International Conference in Honour of Franca Peccchioli Daddi: Florence, February 6th-8th 2014, Firenze, Firenze University Press: 137-155.

Giusfredi F. 2010, Sources for a Socio-Economic History of the Neo-Hittite States, Heidelberg, Universitätsverlag Winter.

Glatz C. 2021, The Making of Empire in Bronze Age Anatolia. Hittite sovereign Practice, Resistance, and Negotiation, Cambridge, Cambridge University Press.

Gonnella J., Khayyata W., Kohlmeyer K., al-Ghafour A. A. 2005, Die Zitadelle von Aleppo und der Tempel des Wettergottes: neue Forschungen und Entdeckungen, Münster, Rhema Verlag.

Harmanşah Ö. 2011, Moving Landscapes, Making Place: Cities, Monuments and Commemoration at Malizi/ Melid, Journal of Mediterranean Archaeology 24: 55-83.

Harmanşah Ö. 2017, Borders are rough-hewn: monuments, local landscapes and the politics of place in a Hittite borderland, in E. L. Baysal, L. Karakatsanis (eds), Bordered Places | Bounded Times. Cross-Disciplinary Perspectives on Turkey, London, British Institute at Ankara Monograph: 37-51.

Hawkins J. D. 2000, Corpus of Hieroglyphic Luwian Inscriptions: Vol. 1. Inscriptions of the Iron Age: Part 1. Text: Introduction, Karatepe, Karkamis, Tell Ahmar, Maras, Malatya, Commagene, Berlin-Boston, De Gruyter.

Hawkins J. D., Weeden M. 2016, Sketch history of Karkemish in the earlier Iron Age (Iron I-IIB), in T. J. Wilkinson, E. Peltenburg (eds), Carchemish in Context: The Land of Carchemish Project, 2006-2010, Oxford-Philadelphia, Oxbow Books: 9-21.

Hawkins J. D., Weeden M., 2017, Kizzuwatna and the Euphrates States: Kummaha, Elbistan, Malatya Philology, in M. Weeden, L. Z. Ullmann (eds), Hittite Landscape and Geography, Leiden-Boston, Brill: 281-294.

Hogarth D. G. 1914, Carchemish: Report on the Excavations at Djerabis. Part I. Introductory, London, Trustees of the British Museum.

Hogarth D. G., Munro J. A. R. 1893, Modern and Ancient Roads in Eastern Asia Minor, Royal Geographical Society 3: 643-744.

Jasiewicz J., Stepinski T. 2013, Geomorphons - a pattern recognition approach to classification and mapping of landforms, Geomorphology 182: 147-156.

Jenness J. 2006. Topographic Position Index (TPI) v. 1.3a, http://www.jennessent.com/arcview/tpi.htm (retrieved on 2021-1-29)

Kiepert R. 1904-19077. Malatja. Karte von Kleinasien, Berlin, Dietrich Reimer (Ernst Vohsen).

Kiepert R. 1913. Malatja. Karte von Kleinasien, Berlin, Dietrich Reimer (Ernst Vohsen).

Kohlmeyer K. 2013, The Temple of the Storm-God of Aleppo, in W. Orthmann, P. Matthiae, M. al-Maqdissi (eds), Archéologie et Histoire de la Syrie I. La Syrie de l'époque néolithique à l'âge du fer, Harrasowitz, Wiesbaden: 511-524.

Kökten I. K. 1960, Anadolu Maraş vilayetinde tarihten dip tarihe gidiş, Türk Arkeoloji Dergisi X/1: 42-52.

Kontani R., Sudo H., Yamaguchi Y., Hayakawa Y., Kulakoğlu F., Emre K. 2012, Preliminary Report for the Archaeological Survey in Kayseri Province, Turkey (KAYAP), Fourth Season (2011), Bulletin of the Okayama Orient Museum 26: 15-29.

Konyar E. 2009, Kahramanmaraş Yüzey Araştırması 2007, Araştirma Sonuçları Toplantısı 26: 175-186.

Konyar E. 2011, Surveys in Kahramanmaraş in 2010, ANMED: News of Archaeology from Anatolia's Mediterranean Areas 9: 174-179.

Liverani M. 1988, The Growth of the Assyrian Empire in the Habur/Middle Euphrates Area: A New Paradigm, State Archives of Assyria Bulletin 2/2: 81-98. 
Llobera M. 2000, Understanding movement: a pilot model towards the sociology of movement, in G. Lock (ed), Beyond the Map. Archaeology and Spatial Technologies, Amsterdam, IOS Press: 65-84.

Llobera M. 2001, Building Past Landscape Perception with GIS: Understanding Topographic Prominence, Journal of Archaeological Science 28: 1005-1014.

Manuelli F. 2016, What remains when contact breaks off? Survival of knowledge and techniques in material culture of the peripheral regions of the Hittite Empire after its dissolution, in E. Foietta, C. Ferrandi, E. Quirico, F. Giusto, M. Mortarini, J. Bruno, L. Somma (eds), Cultural \& Material Contacts in the Ancient Near East. Proceedings of the International Workshop, 1-2 December 2014, Torino, Torino, Apice Libri: 26-35.

Manuelli F. 2019, Carving the memory, altering the past. PUGNUS-mili and the earlier Iron Age rulers at Arslantepe/Malizi (South-Eastern Turkey), in R. Lafer, H. Dolenz, M. Luik (eds), Antiquitates variae. Festschrift für Karl Strobel zum 65. Geburtstag, Rahden/Westf, VML Verlag: 227-241.

Manuelli F., Mori L. 2016, "The King at the Gate". Monumental Fortifications and the Rise of Local Elites at Arslantepe at the End of the $2^{\text {nd }}$ Millennium BCE, Origini 39/1: 209-241.

Maunsell, F. R., 1902. Malatia. Eastern Turkey in Asia (IDWO 1522), London, Great Britain War Office, http:// magma.cnr.it/resource/map/eta/ (retrieved on: 2021-1-10).

Mazzoni S. 1986, A sculptures quarry at Sikizlar, Annales Archéologiques Arabes Syriennes 36-37: 268-275.

Mazzoni S. 1997, L'arte siro-ittita nel suo contesto archeologico, Contributi e Materiali di Archeologia Orientale 7: 287-327.

Mazzoni S. 2000, Crisis and Change: The Beginning of the Iron Age in Syria, in P. Matthiae, A. Enea, L. Peyronel, F. Pinnock (eds), Proceedings of the First International Congress on the Archaeology of the Ancient Near East, Roma, Università di Roma La Sapienza: 1043-1055.

Mazzoni S. 2011, Urban landscape of the Syro-Hittite capitals: models in contact, Mesopotamia 46: 137-155.

Mazzoni S. 2013, Arts and Cross-Cultural Communication in the Early 1st Millennium: The Syro-Anatolian Contact, in Across the Border: Late Bronze-Iron Age Relations between Syria and Anatolia, in K. A. Yener (ed), Across the border: Late bronze-iron age relations between Syria and Anatolia: proceedings of a symposium held at the Research Center of Anatolian studies, Koç University, Istanbul, May 31 - June 1, Leuven-Paris-Walpole, Peeters: 465-492.

May N. N. 2014, Gates and their Function in Mesopotamia and Israel, in N. N. May, U. Steiner (eds), The Fabric of Cities. Aspects of Urbanism, Urban Topography and Society in Mesopotamia, Greece and Rome, Leiden-Boston, Brill: 77-121.

Meriggi P. 1966, Quinto viaggio anatolico, Oriens Antiquus 5: 67-107.

Meriggi P. 1975, Manuale di eteo geroglifico II/3, Roma, Edizioni dell'Ateneo.

Miller J. L. 2012, The (City-)Gate and the Projection of the Royal Power in Hatti, in G. Wilhelm (ed), Organization, Representation, and Symbols of Power in the Ancient Near East. Proceedings of the 54th Rencontre Assyriologique Internationale at Würzburg 20-25 July 2008, Winona Lake, Eisenbrauns: 675-685.

Moortgat A. 1955, Tell Halaf III. Die Bildwerke, Berlin, De Gruyter.

Naval Staff 1919, A Handbook of Asia Minor Volume IV/2. Cilicia, Antitaurus, and North Syria, London, Intelligence Department.

Newhard J. M. L., Levine N., Rutherford A. 2008, Least-cost pathway analysis and inter-regional interaction in the Göksu valley,Turkey, Anatolian Studies 58, 87-102.

Nóvak M. 2012, The Temple of 'Ain Dāra in the Context of the Imperial and Neo-Hittite Architecture and Art, in J. Kamlah (ed), Temple Building and Temple Cult. Architecture and Cultic Paraphernalia of temples in the Levant (2.-1. Mill. B.C.E.), Proceedings of the Conference on the Occasion of the 50th Anniversary of the Institute of Biblical Archaeology at the University of Tübingen (28-30 May 2010), Wiesbaden, Harrassowitz: 41-54.

Orthmann W. 1971, Untersuchungen zur Späthethitschen Kunst, Bonn, Saarbrücken.

Orthmann W. 2002, Die Bildkunst Übergang von der Großreichszeit zur späthethitischen Periode, in E. A. BraunHolzinger, H. Matthäus (eds), Die nahöstlichen Kulturen und Griechenland an der Wende von 2. zum 1. Jahrtausend v. Chr. Kontinuität und Wandel von Strukturen und Mechanismen kultureller Interaktion, Paderborn, Bibliopolis: 153-159. 
Özgüç T., Özgüç N. 1949, Karahöyük hafriyatı raporu 1947: Türk Tarih Kurumu tarafindan yapılan, Ankara, Türk Tarih Kurumu tarafindan Basımevi.

Peyronel L. 2019, Il ruggito del leone. Qualche osservazione sulle immagini ferine nel mondo siriano del III millennio a.C., in S. Valentini, G. Guarducci (eds), Between Syrian and the Highlands. Studies in Honor of Giorgio Buccellati and Marilyn Kelly-Buccellati (Studies on the Ancient Near East and the Mediterranean 3), Roma, Arbor Sapientiae: 323-334.

Poli P. 2008, Traduzione, assimilazione, interpretazione di elementi iconografici ed ideologici da tradizioni diverse. Il caso di Malatya, in B. Bellucci, E. Jucci, A. Rizza, B. M. Tomassini Pieri (eds), Traduzione di tradizioni e tradizioni di traduzione. Atti del quarto incontro "Orientalisti" (Pavia, 19-21 Aprile 2007), Milano, Qu.A.S.A.R.: 249-276.

Polla S., Verhagen P. 2014, Computational approaches to the study of movement in archaeology. Theory, practice and interpretation of factors and effects of long term landscape formation and transformation, Berlin, de Gruyter.

Pucci M. 2015, Founding and Planning a new Town: the southern Town Gate at Zincirli, in P. Ciafardoni, D. Giannessi (eds), From the Treasures of Syria. Essays on Art and Archaeology in Honour of Stefania Mazzoni, Leiden, Nederland Institute for the Near East: 35-74.

Ramsay W. M. 1890, The Historical Geography of Asia Minor, London, RGS.

Ramsay W. M., Hogarth D. G. 1893, Pre-Hellenic Monuments of Cappadocia (2), Recueil de travaux relatifs à la philologie et à l'archéologie égyptiennes et assyriennes 15: 89-97.

Riis P. J., Buhl M.-L. 1990, Les objets de la période dite syro-hittite (Age du Fer), Hama II/2, Copenhagen, Fondation Carlsberg.

Scheinhardt H. 1979, Typen türkischer Ortsnamen, Heidelberg, Carl Winter.

Seeher J. 2009, Die Techniken der Steinbearbeitung in der hethitischen Architektur des 2. Jahrtausends v. Chr, in M. Bachmann (ed), Bautechnik im antiken und vorantiken Kleinasien: Internationale Konferenz 13.-16. Juni 2007 in Istanbul, Istanbul, Ege Yayınları: 119-156.

Simon Z. 2013, Wer war Großkönig I(a)+ra/i-TONITRUS der Karahöyük-Inscchrift?, in L. Feliu, J. Llop, A. Miller Albà, J. Sanmartín (eds), Time and History in the Ancient Near East. Proceedings of the 56th Rencontre Assyriologique Internationale at Barcelona, 26-30 July 2010, Winona Lake, Eisenbrauns: 823-832.

Sterrett J. R. S. 1888, An Epigraphical Journey in Asia Minor, Boston, Damrell \& Upham.

Surface-Evans S. L., White D. A. 2012, Least Cost Analysis of Social Landscapes, Salt Lake City, The University of Utah Press.

Strawn B. A. 2001, "What is Stronger Than Lions"? Leonine Image and Metaphor in the Hebrew Nibble and the Ancient Near East (PhD Thesis), Faculty of Theological Seminary, Princeton University.

Summers G. D., Özel E. 2012, The Hittite Stone and Sculpture Quarry at Karakız Kasabası and Hapis Boğazı in the District of Sorgun, Yozgat, Central Anatolia, American Journal of Archaeology 116/3: 507-519.

Tilley C. 1994, A phenomenology of landscape: places, paths and monuments, Oxford, Berg Publishers.

Tunca Ö. 1976, The Lion of Çolaklıköy, Anatolian Studies 26: 113-16.

Uysal B., Çifçi A. 2019, Elbistan Karahöyük Kazısı, Kazı Sonuçları Toplantısı 41/1: 411-422.

Veselský M., Bandura P., Burian L., Harciníková T., Bella P. 2015, Semi-automated recognition of planation surfaces and other flat landforms: a case study from the Aggtelek Karst, Hungary, Open Geosciences 1: 799-811.

Von der Osten H. H. 1930, Explorations in Hittite Asia Minor, 1929 (OIC 8), Chicago, University of Chicago Press.

Von Luschan F. 1902, Ausgrabungen in Sendschirli. Vol. 3, Thorsculpturen. Berlin, Georg Reimer.

Wilhelm G. 2011, Combining textual and archaeological evidence of urban structures: Hattusa and Sarissa, Mesopotamia 46: 103-108.

Woolley C. L. 1921, Carchemish: Report on the Excavations at Djerabis. Part II. The Town Defenses, London, Trustees of the British Museum.

Woolley C. L. 1952, Carchemish: Report on the Excavations at Djarabis. Part III. The Excavations in the Inner Town; The Hittite Inscriptions, London, Trustees of the British Museum.

Yusufoğlu H. 2013, An intramontane pull-apart basin in tectonic escape deformation: Elbistan Basin, Eastern Taurides, Turkey, Journal of Geodynamics 65: 308-329. 